\title{
Transformación del espacio doméstico en el Madrid del siglo XVIII: del oratorio y el estrado al gabinete*
}

\author{
JESUSA VEGA \\ Departamento de Historia y Teoría del Arte \\ Facultad de Filosofía y Letras \\ Universidad Autónoma de Madrid
}

\section{RESUMEN}

El cambio que tuvo lugar en la decoración de interiores a mediados del siglo XVIII en España se inició en los palacios reales y de la nobleza pero progresivamente se fue extendiendo al resto de la población. Como consecuencia de ello creció la actividad comercial de obras de arte que claramente quedó reflejada en los anuncios que se insertaron en el Diario de Madrid. A partir de la información que suministra este periódico se puede llegar a conocer mejor el gusto en el adorno de los interiores domésticos, especialmente del oratorio y el gabinete, centrándonos en esta ocasión de manera particular en la escultura cuya temática era mayoritariamente religiosa.

Palabras clave: Gusto, Decoración, España, Siglo XVIII, Escultura.

\section{SUMMARY}

The change that took place in Spain in the $18^{\text {th }}$ century in interior decoration started in the royal palaces and among the gentry; from there it spread to the rest of the population. Trade in works of art grew as a result, as reflected in the ads of Diario de Madrid. With the information furnished by this magazine one can know better the tastes in decoration for home interiors, especially that of the cabinet. The author here focuses on sculpture, the themes of which were mostly religious.

Key words: Taste, Decoration, Spain, $18^{\text {th }}$ Century, Sculpture.

* Este artículo es la segunda parte del publicado en esta misma revista, tomo LV, cuaderno primero, 2000, pp. 5-43. Un resumen se presentó en el congreso "Nature and Reality: Spanish and Portuguese Art in the Eighteenth Century" (Dublin 16-17 de julio de 2004) y la investigación se ha desarrollado en el marco del proyecto "Cultura visual: la construcción de la memoria y la identidad en la España Contemporánea" (BHA 2001-0219). No podría haber escrito estas páginas sin el apoyo y la generosidad de Eduardo García Agustín, Nigel Glendinning y Margarita Estella; también deseo agradecer la ayuda que en todo momento me han prestado Concha Herrero, Jo Labanyi, Ronda Kasl, José de la Mano, Luis Fernández Colorado, Carlos Domínguez, María Jesús Herrero y Antonio Cea.

RDTP, LX, 2 (2005): 191-226 
El lujo o austeridad del adorno doméstico ha sido un tema que siempre ha merecido la atención desde el punto de vista social, político y económico, debido a su importancia como vitrina y modelo de los grupos de poder. Evidentemente en el Antiguo Régimen es la monarquía la que marca la pauta y sus gustos son los que, tarde o temprano, penetran en una buena parte del cuerpo social. Esos gustos siempre estuvieron en el punto de mira y, visto con perspectiva histórica, es fácil comprobar que hay algunas críticas constantes que se encuentran por igual en época de los Austrias y de los Borbones, tal es el derroche de caudales que supone el adorno de salas y aposentos. Si nos acercamos a la literatura sobre el tema durante el reinado de Felipe III y hacemos lo propio un siglo más tarde, podremos constatar que hasta las posibles soluciones son prácticamente las mismas: contener el gasto suntuario para tratar de educar a la sociedad en una austeridad ejemplarizante, eso sí sin renunciar a la dignidad del adorno personal y doméstico que a cada uno correspondía según su clase. De este modo también se contribuía a la riqueza nacional porque se rechazaba aquello que no se fabricaba en el país en favor del fomento de la industria local, aunque sus productos fueran menos sofisticados que los de procedencia extranjera.

Gracias a esta misma literatura podemos conocer un poco mejor esos adornos domésticos y completar en parte el contexto de procedencia y destino de aquellos objetos que, como veremos, se pusieron a la venta a lo largo del siglo XVIII (la información más rica corresponde a los años centrales de la centuria). Excelente ejemplo de la época de Felipe III es el escrito reprobatorio de Pedro Fernández de Navarrete, Conservación de monarquías. Discursos políticos sobre la gran consulta que el Consejo bizo al Señor Rey don Felipe Tercero (Madrid, 1626). En el Discurso XXXV que trata "Del exceso en los edificios y alhajas" ha quedado una buena síntesis descriptiva de aquello que se podía encontrar en las casas adineradas: artesones dorados, chimeneas de jaspes, columnas de pórfidos, "camarines de exquisitas bujerías con infinidad de escritorios, que sirven sólo a la perspectiva y correspondencia, tantos y tan variados bufetes, unos embutidos de diferentes piedras, otros de plata, otros de ébano y marfil y otras mil diferencias de maderas traídas de Asian. Y continúa:

ya no se juzga qué huelen las flores, si los ramilleteros son de barro: y así los hacen de plata, o de otra manera más costosa [...] no sólo los ramilleteros son de plata, sino que aún se hacen los tiestos y potes para las hierbas de este tan estimado metal. Tampoco se contentan ya los hidalgos particulares con las colgaduras, que pocos años antes adornaban las casas de los Príncipes. Los tafetanes ${ }^{1}$ y

${ }^{1}$ Las colgaduras de tafetanes eran también habituales en el adorno interior de los templos con motivo de las fiestas, y podían ser en propiedad o alquilados. En la Sierra 
guadamecíes de España, tan celebrados en otras Provincias, ya no son de provecho en ésta. Las sargas y los arambeles con que se solía contentar la templanza Española se han convertido en perjudiciales telas rizas de Milán y Florencia y en costosísimas tapicerías de Bruselas y para piezas en que no se ponen colgaduras, se traen extraordinarias pinturas, valuándolas por sola la fama de sus autores y muchas de ellas con menos honestidad de la que conviene a casas de cristianos: trayéndoles así mismo otros mil impertinentes adornos (pp. 245-246).

Estos interiores del siglo XVII son los que se van a transformar profundamente en el XviII y buena parte de los objetos que servían de adorno saldrán al mercado mezclados, eso sí, con los de nueva hechura siguiendo los gustos del día. La venta de lo antiguo y lo nuevo se anunciará por igual durante la década 1758-1769, años de verdadera prosperidad para la ciudad de Madrid (Ringrose 1985: 78), en los que hubo una renovación del gusto en la decoración doméstica como consecuencia del dinamismo constructor y del proceso de cambio que había tenido lugar en los palacios y residencias de la corona y que, en este momento, se hace extensivo a otras casas nobles y cortesanas ${ }^{2}$.

Entre las salas y dormitorios donde se fueron distribuyendo estos objetos cabe destacar una pieza doméstica que va afianzándose en el curso del siglo: el gabinete. El gabinete resultará una habitación fundamental en las casas madrileñas que se precien a partir de la segunda década del XVIII y, de hecho, muchos de los objetos de arte se anunciarán con ese destino. En cierta medida el gabinete se puede considerar el heredero de esos camarines atiborrados de objetos diversos que constituían el oratorio, y es relativamente frecuente encontrar anuncios donde la oferta se considera adecuada para lucirla en ambos ${ }^{3}$. Esto es fácil de entender. Como

de Francia hay documentados ejemplos de tafetanes de distintos colores, nuevos y viejos, de alquiler o en propiedad durante los siglos XVII y xvIII (Cea Gutiérrez 2000: 130-131).

${ }^{2}$ Fue este un periodo de expansión y reconstrucción urbana - la construcción fue la actividad industrial dominante en esos años-, en el cual más de la mitad de la población madrileña empleada en las manufacturas en 1757 se dedicaba a elaborar artículos de lujo destinados a la pequeña y bien definida 'élite' madrileña (Reingrose 1985: 90, 91 y 100).

${ }^{3}$ Eran bastantes los objetos que servían indistintamente para ámbitos civiles o religiosos, por ejemplo los aguamaniles: "Se vende un aguamanil de jaspe, sin estrenar, propio para una Sacristía, Oratorio, o para una sala de señores, por ser muy bien trabajada, darán razón en casa de Mr. Paul que vive en los cuartos del pasadizo de Don Francisco Salcedo, calle del Tesoro" ( $D N, 16$. septiembre. 1758); "En la casa de nuestra Señora de la Almudena que está junto a la Iglesia de San Antonio de los Portugueses, frente de la fuente, se vende un aguamanil de piedra jaspe hecho a la similitud de una Rinconera primorosamente trabajada y muy a propósito para cualquiera convento de Señoras religiosas u de algún señor para su sala" $(D N, 274,28$. julio. 1761). 
advierte Martínez Burgos (1990: 200-201), en los oratorios se reunían diversidad de objetos, tanto religiosos (pinturas de santos, vírgenes o crucifijos con incrustaciones de piedra y metales preciosos, relicarios, ornamentos, lámparas y candelabros de plata, sábanas y casullas), como de mero lujo o adorno: colgaduras y tapices, tallas de animales en marfil, oro y ámbar, camafeos, calabazas y calabacines en azabache y oro, y un sinfín de cosas dispares que explican las críticas de san Juan de la Cruz para quien "componer y adornar oratorios" nada tenía que ver "con la auténtica oración". Por último, aunque el asunto religioso dominará por largo tiempo la temática de los cuadros que cubrían las paredes de las habitaciones - pensemos en la descripción que da William Beckford del cuarto que ocupó en casa del veterano coronel de Santa Olalla (Boyd 1954: 286) - , el proceso de cambio hacia temas profanos fue creciente e imparable desde comienzos del siglo XviII. Así le hace hablar Torres Villarroel, hacia 1728, a su difunto Quevedo en una de las visitas a un domicilio madrileño:

También he reparado - prosiguió mi muerto- que en esta sala no hay imagen alguna de Cristo, de su Madre, ni de otro santo de los innumerables que viven eternamente en la compañía de Dios; las paredes desnudas, sin más abrigo que esas cortinas y silletas.

- Perdiose la devoción — le dije-, y con ella el gusto a la pintura.

Y Quevedo prosiguió:

-Un cuadro penitente enfrena al más desbocado. Una efigie honesta sirve de despertador a la templanza. Y todas nos acuerdan los premios de la cristiana religión.

- Ya en todas las piezas que sirven al estrado ${ }^{4}$ no se usa más adorno que esta desnudez - le dije-. En las antesalas se suelen ahorcar algunas pinturas. Ven conmigo a este recibimiento, y notarás la inclinación de los españoles en los objetos que tiene para divertir la vista.

Salimos afuera, y en la pieza interior había multitud de papeles y láminas de deshonestos mamarrachos: un hombre vomitándose, otro bebiendo, otro meando, un cartelón en que rodeando a una mesa se registraban varias figuras fumando y engullendo, otro en que se reconocía un galanteo y una disolución, y otras copias ridículas que movían más a lo vicioso que a la carcajadas5.

${ }^{4}$ Se dio, lógicamente, una progresiva desaparición del estrado, razón por la cual también se pusieron a la venta. Sirva de ejemplo el siguiente anuncio: "Se vende un estrado completo, compuesto de doce taburetes altos y ocho pequeños, un canapé de cuatro asientos, igual a los pequeños, todo nuevo cubierto de damasco carmesí con la clavazón dorado" ( $D N$, 16. enero. 1761).

${ }^{5}$ Como anota Russel P. Sebold, la descripción de las estampas recuerdan a las series de Hogarth, grabador inglés contemporáneo del autor español (Torres 1991: 203204). Como explica N. Valverde Pérez (2003: 213-14) el predicador José María Antonio López Cotilla en su Epifanía Mariana o Manifestación prodigiosa de María Santísima, madre de Dios y nuestra, en su muy perfecta imagen, bajo la singular advocación 
Este cambio de las costumbres en la decoración hizo que la múltiple variedad de objetos que se reunieron en las salas y habitaciones durante el siglo XVII acabaran en muchas ocasiones en prenderías y tiendas diversas (piénsese de dónde podía proceder un vaso de asta de unicornio que se vendía en la abaniquería del Postigo de San Martín, Diario Noticioso, 6. febrero. 1759$)^{6}$, y también provocó profundas renovaciones de los interiores que implicaban cambios espaciales de tal envergadura que explican que uno de los primeros anuncios publicados en el Diario Noticioso fuese dirigido a aquel que necesitara o quisiera "comprar dos columnas de pórfido, de la altura de dos varas y el grueso correspondiente de alabastro preciosas" (3. febrero. 1758).

En ese progresivo afianzamiento del gabinete existe un verdadero hito que ayuda a comprender la evolución, el de la reina Isabel de Farnesio en el Palacio de Aranjuez, cuya compleja y artificiosa construcción (obra del adornista italiano Juan Bautista Galuzzi terminada por su compatriota Santiago Bonavía), y elevado gasto, estudiado por Virginia Tovar (1996: 35-44). Se llevó a cabo entre 1728 y 1738 y, según se describe, fue un espacio no muy amplio, en el cual también existía un pequeño oratorio. En el desarrollo de los trabajos se dieron cita el misterio (ni siquiera hubo planos y se cerraba con llave para que nadie pudiera acceder sin autorización), el ingenio y el artificio (una fuente portátil, juegos de agua, pinturas ilusionísticas y elaboradas perspectivas), el colorido (se proyectó con todo tipo de mármoles de colores aunque finalmente se optó por el estuco y la madera), y una lujosa vistosidad llena de dorados, bronces y espejos, algunos de los cuales eran de un tamaño tal que hubieron de ser fabricados a medida en un taller de París. Desde luego no cabe duda del impacto visual que causaba, ya que, además de la riqueza y amenidad del conjunto, dominaba la teatralidad de la escenografía arquitectónica. Debía ser un magnífico ejemplo de esa preocupación del arquitecto por los elementos ornamentales y pictóricos que llevaba a esa combinación de actividades pintor/arquitecto en la remodelación de interiores, tan a la moda en Francia e Italia (Ciechanowiecki 1990: 44). Todo esto se completaba con gran variedad de adornos tallados en madera, dados de blanco o dorado, en puertas, antepuertas, cornisas, marcos, etc., así como con “jaulas,

de la Bien Aparecida, reverentemente aclamada, y obsequiosamente servida por la Nobilísima y Pía, recién fundada congregación de nacionales (Madrid, viuda de Manuel Fernández, 1753), exponía de modo teatral el desconcierto y la estupefacción del pío cuando era invitado a estos sus gabinetes, tan de moda, que llenos todos de fábulas gentilicias, medallas, y países de mentidas deidades, no hallando entre ellos, ni una imagen de Cristo, ni una efigie de Marían.

${ }^{6}$ En adelante $D N$. 
sillas y otros muebles" y máquinas. Entre estas últimas tuvo verdadero impacto la que se colocó en un balcón. Estaba compuesta por:

juegos de agua en un peñasco grande con cuatro cabezas de vientos, y otros pequeños con conchas y tazas de mármoles y varias figuras de bronce: un Neptuno grande, cuatro delfines, un león con una flor de lis en la mano [símbolo de la unión de España con Francial, y otro en ademán de beber; una sirena, un fauno y unos árboles con pájaros, y otras invenciones?

De la fascinación de los españoles por las máquinas ha quedado claro testimonio y fue una verdadera moda el gabinete de máquinas entre la clase acomodada, resultando característico el descrito por Ramírez de Góngora en su Óptica del cortejo (Valverde Pérez 2003: 33, 55, 192 y 213). Se podían adquirir autómatas $(D N, 15 \text {. febrero. } 1758)^{8}$, todo tipo de entretenimientos ópticos como cajas ópticas y cámaras oscuras (Portús y Vega 1998: 84-88), microscopios9 ${ }^{9}$ y desde luego fuentes y máquinas eléctricas. Entre las primeras se ofertó el 31 de diciembre de 1760 unna fuente para la diversión en una sala, estribando en su carro de cuatro ruedas, con el cañón de plomo, pila y depósito del agua, todo bastante mudablen; y entre las segundas el 10 de marzo de 1764 se anunciaba "una maquina eléctrica con particulares experiencias como son las de la botella preparada, repique de campanillas, cuadro y compás mágico y otros muchas que se harán demostrables [...] en casa del Manguitero que está en el Sotanillo de la calle de las Veneras inmediato al convento de Religiosas de nuestra Señora de los Ángeles".

En este contexto de cambio se debe situar, no sólo el activo mercado del arte de mediados de siglo, sino también la labor de muchos artistas

7 Debía llamar desde luego la atención ya que es lo único que describe Juan Antonio Álvarez de Quindós (1982: 193-4) en 1804. La máquina se dio por concluida el 9 de mayo de 1733 (Tovar 1996: 39).

${ }^{8}$ Resultan relevantes los anuncios insertados por el maquinista Antonio Labal para que el público acudiera a la calle de la Montera a ver su espectáculo de autómatas (DN, 4. diciembre. 1765) donde se manifestaba un edificio en construcción bajo la supervisión del propietario, y el reloj de más de 3.204 figuras en movimiento ( $D N$, 28. enero. 1766). La fascinación por los autómatas pervivió largo tiempo en España y era una atracción popular a finales del siglo XIX cuyo declive se debió en gran parte al cinematógrafo (Sánchez Vidal 1994: 112-114).

9 "La persona que quisiere comprar un Microscopio o Linterna Mágica Solar como la que describe el Padre Zacagnini en su Physica Experimental. Una prueba de su prodigioso aumento se verá en la Estampería que hay en la calle de Alcalá" ( $D N, 22$ diciembre 1762). En realidad el autor fue el francés Jean Antoine Nollet quien alcanzó fama y prestigió en toda Europa con sus lecciones, especialmente con las demostraciones con la máquina eléctrica; la traducción de Antonio Nicolás Zacanini vio la luz en 1757 en la prestigiosa imprenta madrileña de Joaquín Ibarra. 
y maestros que ofrecían sus servicios al público a través de las páginas de los periódicos, principalmente del Diario Noticioso. Los muebles viejos podían ser transformados o deshechos para adaptarse al nuevo espacio sin desentonar con los modernos. Por ejemplo, ese destino se proponía para dos escritorios de dos varas de largo y vara y media de alto, fabricados en Nápoles "cubiertos de ébano y concha, con los bronces dorados de molido, con siete cajones cada uno y cristales pintados de miniatura" ( $D N, 12$. noviembre. 1760). También habían pasado de moda las tapicerías, arte en el cual se hizo muy evidente el cambio de gusto tras el establecimiento de la Real Fábrica de Tapices. Se abandonaron los temas históricos, mitológicos y heroicos en favor, primero, de los temas costumbristas al modo de Teniers, y finalmente, tras la llegada de Anton Raphael Mengs, de los asuntos jocosos y grotescos de los Bayeu, Castillo o Goya. Por esta razón se anunció reiteradas veces la venta de series tejidas en siglos anteriores en las afamadas manufacturas de Bruselas y Amberes con la Historia de Diana (11 paños), la Historia de Rómulo y Remo (8 paños), El rapto de Helena y destrucción de Troya (8 paños), la Historia de Hércules (8 paños), la Historia de David (15 paños), Judith y Holofernes (5 paños) la Historia Sagrada (6 paños), la Historia de la vida del hombre (13 paños), etc. (Herrero Carretero 1996: 80-82); también eran antiguas las tapicerías decorativas que se ofrecieron con motivos de arboledas, columnas, figuras, ramilleteros... ${ }^{10}$.

En contraposición, hubo una oferta continua de toda suerte de imitaciones de tapices para adornar las paredes, pero eran pintados, adaptados a las dimensiones del gabinete y a los gustos del día. Se podían encargar estas "tapicerías" a la fábrica establecida en Aragón ( $D N, 21$. diciembre. 1758), o adquirirlas en el mercado local como los "cuatro tapices de gabinete, pintados en lienzo con zumo de hierbas al uso de Italia" ( $D N, 13$. abril. 1758); o bien se encargaban, por ejemplo, al sujeto extranjero establecido en la Corte, que el 23 de febrero de 1759 anunciaba su "habilidad para pintar todo género de tapices [...] de Marina, de Historia y todo cuanto se le pidan. En este sentido cabe citar la actividad desarrollada por ael profesor de pintura natural y vecino de esta corte, discípulo de la Aca-

${ }^{10}$ La tapicería fue un elemento fundamental en la decoración doméstica, prueba de ello es el próspero negocio de venta y alquiler de tapices que tuvo la familia Fourdinier; en el obrador de José María Fourdinier "se almacenaban un centenar de ellas con casi 900 paños en diferente estado de conservación. Un conjunto de 8 paños en buen estado podía alcanzar la cifra de 6.800 rs., como uno de los grupos dedicados a la Historia Antigua de los Romanos. Predominan los temas mitológicos, de Historia Antigua, del Antiguo Testamento y decorativos" (Blanco Mozo 1998: 305). 
demia de San Fernando", Manuel Rodríguez Palomino"1, quien había "inventado y perfeccionado" a solicitud del conde de Floridablanca "un nuevo género de colgaduras y tapicerías al óleo, hechas con las borras o lanas de los paños viejos, haciendo con ellas Tapicerías historiadas y Colgaduras de ornatos" cuya ventaja era que no podían "crear polilla, ni otro insecto por ser su composición al óleo" y se podían lavar "sin que decaigan en su composición y color. De hecho hizo, a instancias del conde de Montijo, una demostración al rey. Estas colgaduras se realizaban sobre raso, tafetán y sarga, y, según declaración del interesado, aventajaban een su hermosura y duración a toda Tapicería y Tejidos" (Espiritu de los mejores diarios, 28 de julio de 1788, v. IV, p. 92).

A pesar de la durabilidad con la que se anunciaban, no son muchos los ejemplos que han sobrevivido de estas tapicerías pintadas en las que la gruesa textura de la tela servía para crear un efecto que se asemejaba al tapiz aunque, por la técnica empleada, es una manera de trabajar que guarda más relación con la tradicional pintura sobre sarga que con la actividad de los tapiceros. En el Museo Municipal de Madrid se conserva un juego de cuatro vistas que da una idea de cómo era este tipo de adorno: una bella vista nevada del Palacio Nuevo desde la Cuesta de la Vega, donde es más importante el paisaje que la fábrica y que recuerda al famosísimo cartón goyesco de La nevada con ese tipo popular con su mula en primer plano (fig. 1). Quizá, además, estuvieran representadas las estaciones del año y así la vista del estanque del Buen Retiro con la Real Fábrica de Porcelana al fondo y una falúa en primer plano es posible que represente una tarde de primavera con los característicos cielos rosados crepusculares de Madrid (fig. 2). La vista del Paseo del Prado con la fuente de la Cibeles incorpora gentes sentadas a la sombra observando una parada militar e invita a pensar en el verano (fig. 3); y, finalmente, la vista de la Puerta de San Vicente con el palacio al fondo, parece otoñal por el tono de las hojas de los árboles (fig. 4). Desde luego el conjunto resulta muy decorativo, con sus llamativas y coloreadas cenefas de flores rodeando los simulados marcos de madera. Este tipo de telas iban fijas a la pared y colocadas del mismo modo que las nuevas decoraciones de tapices de la Real Fábrica para las habitaciones de los príncipes en El Pardo o El Escorial. Es decir, sujetas y atrapadas por enmarques a los muros suplantando, como explica Herrero Carretero (2004: 26), «la

${ }^{11}$ Apenas se tienen noticias de este pintor. Sabemos que cuando se ordenó a Goya comparecer ante el Tribunal de la Inquisición con motivo de La Maja Desnuda en 1814, se pensó también interrogarle en relación con este Rodríguez Palomino que, al parecer, había pintado una Venus desnuda (Glendinning 1983: 41). 


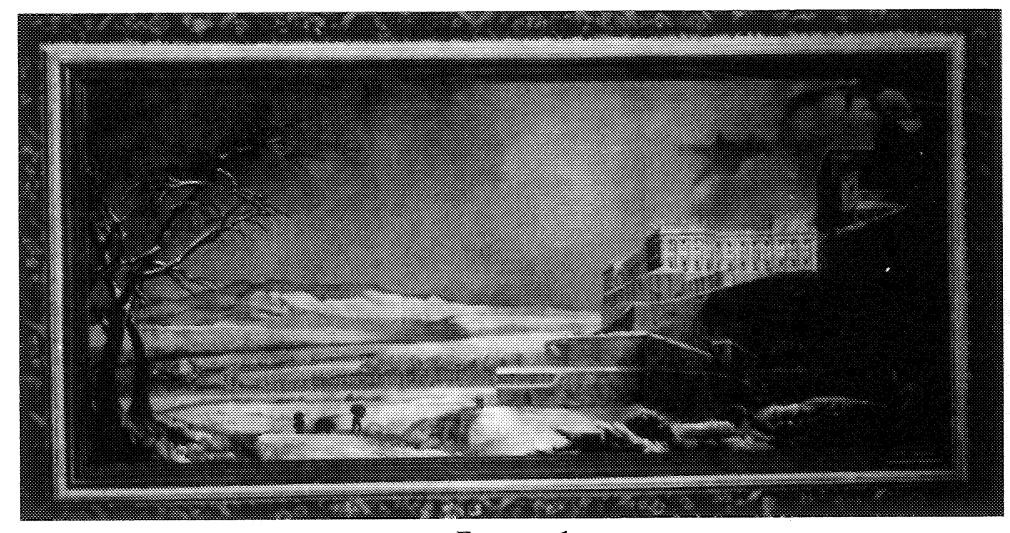

FIGURA 1

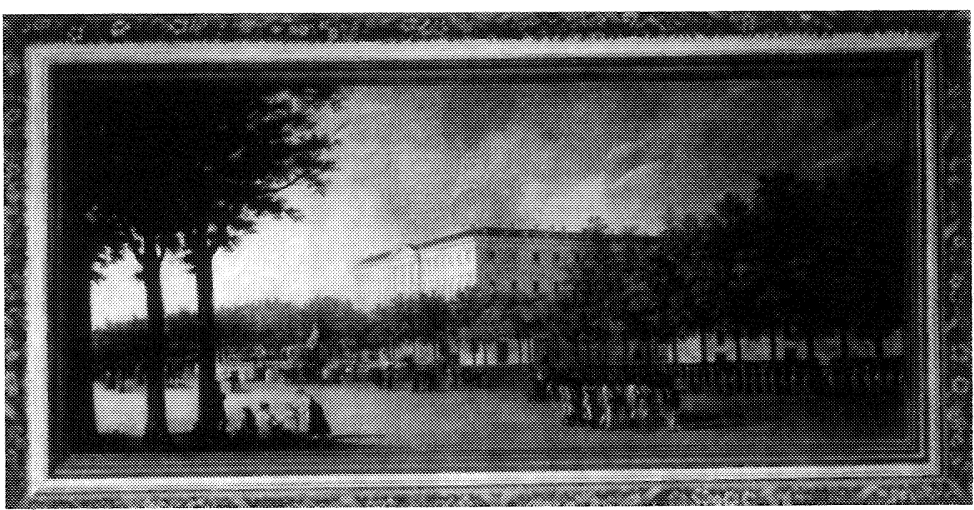

FIGURA 3

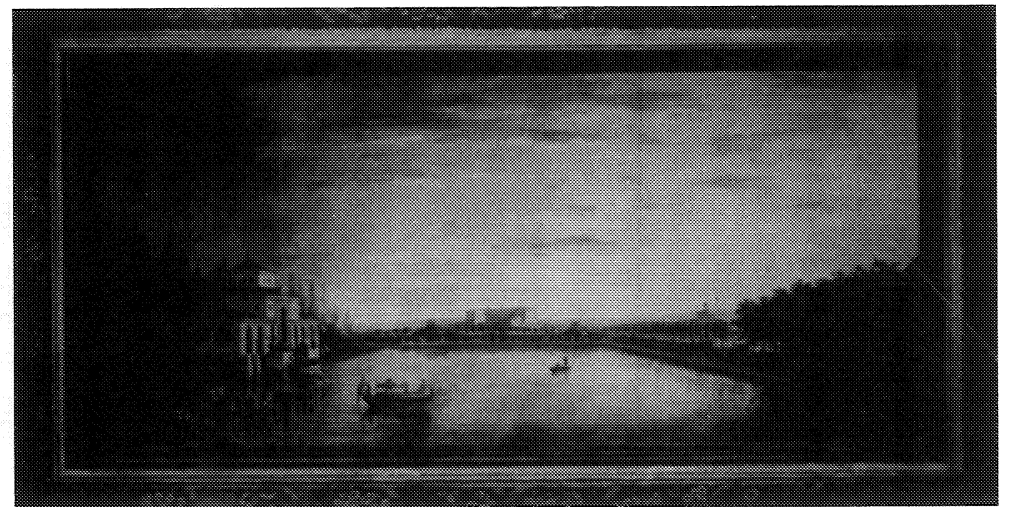

FIGURA 2

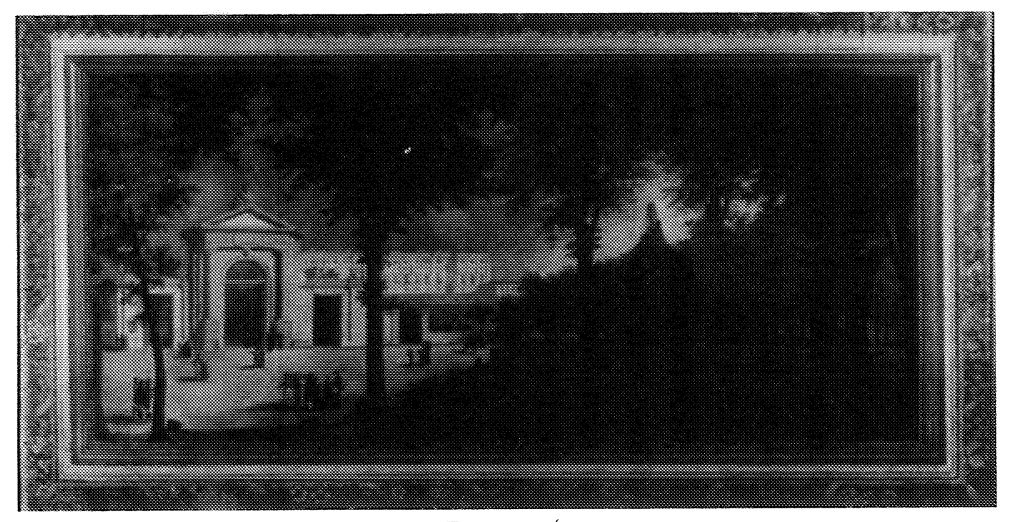

FIGURA 4 
antigua condición de colgadura móvil y acentuando su carácter decorativo como 'cuadro tapiz'.

Aunque los cuatro paños que se conservan en el Museo Municipal de Madrid se han venido fechando hacia $1815^{12}$, la presencia de la Fábrica de La China hace suponer que sean anteriores por lo menos a la Guerra de la Independencia; no obstante, después de la contienda siguió empleándose este tipo de adorno incluso por la misma monarquía, ya que en la actualidad se conservan en Patrimonio Nacional tres vistas del Palacio Real y un paisaje rural copiando otras tantas pinturas de Fernando Brambilla en las que la cenefa es muy similar a las anteriores pero se ha prescindido del color, creando un efecto más ilusionístico de marco de madera tallado $^{13}$.

Para los tapices, como para otros muchos objetos, principalmente pinturas y abanicos, había variedad de especialistas dedicados a limpiarlos, recomponerlos o adaptarlos. En cuanto a los abanicos son múltiples los anuncios de profesionales dedicados a estos menesteres y a montarlos para su exposición (Vega 2000: 24-25) y, si creemos a Ceán Bermúdez (1800: v. I, 226), todavía en su tiempo se cotizaban los abanicos pintados por Juan Cano y Arévalo aunque estuvieran ya inútiles para dar aire, circunstancia que no mermaba su aprecio entre los entendidos; el mismo Palomino conservaba uno por considerarlo "una alhaja de gran estimación" (Palomino 1947: 1072-73).

La actividad de limpiar, recomponer, acomodar o restaurar pinturas no fue menor. A ella se dedicaron no sólo los pintores ${ }^{14} \mathrm{y}$, entre los anun-

${ }^{12}$ Esa cronología se les dio en "la Exposición del Antiguo Madrid" (AA. VV. 1926: núm. 245 y 246) y se ha mantenido aunque están pendientes de ser estudiados. Agradezco a Isabel Tuda la información y ayuda que en todo momento me ha prestado.

${ }^{13}$ Los lienzos pintados para ser adosados a la pared de Fernando Brambilla que se conservan en el Palacio Real muestran: "Paisaje de montaña con río", "paisaje de montaña con casas de labor y establo" y "paisaje con casas y figuras de campesinos" (números de inventario 1003955, 1003956 y 10039557 respectivamente); de este mismo pintor y similares técnicamente son la "Vista del palacio Real de Madrid" (n.․ inv. 10006195), una "Vista de Madrid desde el Manzanares" (n.. inv. 10078150) y "Vista de la fachada del Patio de la Armería del Palacio Real de Madrid" (n.. inv. 10006013). Quizás hay que llamar la atención sobre otra actividad donde también debieron introducirse novedades en estos años; nos referimos a los telones de boca teatrales, pintados con la misma técnica y en el mismo tipo de tejido (por lo menos los que se conservan en el Palacio Real, obra del citado Brambilla, son muy similares).

${ }^{14}$ Se puede decir que había limpiadores en general; por ejemplo el que limpiaba y blanqueaba lámparas también hacía lo propio con las pinturas $(D N, 28$. septiembre 1758); el de plata advertía que también limpiaba aaltares dorados, los marcos de pinturas, las mismas pinturas y otra cualquiera obra de esta naturaleza que quisieren 
cios, registramos también la presencia de extranjeros que se ofrecían para tratar obras en cualquier tipo de soporte y procedimiento, además de levantar barnices, quitar repintes o alterar de tamaño para adecuarlas al espacio sin que se notara en su caso lo añadido, forrarlas o cambiarlas de soporte, actividad que en estos años era motivo de debate en Francia debido a los trabajos de Robert Picault. Pero en el caso español se debe tener muy presente el incendio en el antiguo Alcázar de los Austrias, ya que supuso una labor ingente, casi podríamos decir frenética, de restauración en lo que se refiere a las pinturas, no sólo en el sentido de reparar los daños provocados por el humo, el calor y el fuego, sino también porque el cambio de ubicación que necesariamente habrían de sufrir comportaba una nueva distribución; dicho en otras palabras, una redecoración. Esto revitalizó la alteración de los tamaños ya que se siguió el tradicional "criterio de galleria", para adaptar las obras a sus nuevos destinos. En estos trabajos se vieron involucrados múltiples pintores, los cuales eran también responsables de tratar las pinturas que se seguían adquiriendo: piénsese en el retrato del Conde Duque de Olivares que fue forrado y agrandado por Andrés de la Calleja, uno de los artistas más activos en este sentido en aquellos años (Martínez Justicia 2000: 159-60).

Por el Diario Noticioso sabemos que en la calle de Preciados, frente a las monjas de Constantinopla, vivía un "Pintor de profesión" que sabía componer pinturas "ya sean de lienzo, en tabla o en cobre, quita cualquier barniz secante o retoques de otra mano como no sea la del autor original, añade las pinturas si es menester, en largo o en ancho, las corta y aforra, y se atreve a trasladar la pintura de un lienzo a otro con advertencia que si la echare a perder pagará todo el valor de la Pintura" ( $D N$, 9. febrero. 1758). Hubo cierto concurso de artistas extranjeros dedicados a estas actividades de "restauración" como el alemán Santiago Lupre que se ofrecía a limpiar todo género de pinturas "y dejarlas casi nuevas, por antiguas o imperceptibles que estén" ( $D N, 24$. noviembre y 29. diciembre. 1758), o el napolitano que añadía a éstas habilidades la de un secreto para trasladar una pintura vieja sobre un lienzo nuevo, compone los cuadros hechos pedazos y los pone en su perfección" ( $D N, 20$. noviembre. 1760). Podemos hacernos una idea del tratamiento que se hacía "para limpiar los cuadros viejos que parezcan como nuevos" en estos años. Esta sencilla receta se insertó en el Semanario económico (1766: I, 167):

conservar" ( $D N$, 23. junio. 1759); Paula Fernández tenía "habilidad y un secreto para limpiar láminas, retablos dorados, espejos y otro cualquier dorado sobre madera" $(D N, 9$. junio. 1760). 
Échese en un puchero un cuarterón de barrilla en polvo, desmenúcese sobre ella un poco de jabón bueno, y con agua se hará hervir todo por espacio de un cuarto de hora, en estando tibia el agua se lavará con ella el cuadro, después se enjugará y se le dará con aceite común y se volverá a enjugar. De esta suerte, como la pintura no esté saltada quedará el cuadro viejo como si fuera nuevo.

En cuanto a la transferencia de soportes se han conservado distintas recetas, algunas de ellas manuscritas como la anónima y sin datar que se guarda en el archivo del Palacio Real de Madrid y es como sigue:

Primeramente se encolará papel sobre la pintura procurando que en ningún caso quede aire entre ésta y el papel. La cola se hará de engrudo añadiendo un poco de miel.

Se sierra la tabla en que está la pintura dejando la parte en que está reducida al mínimo posible, y en seguida se tiende sobre una superficie plana con la pintura cubierta con el papel debajo para que un carpintero diestro con herramientas delicadas pueda apurar la tabla que queda hasta llegar a la imprimación que generalmente los pintores antiguos la usaban de yeso y cola, y por esto se ha de cuidar de no poner agua, quitando la madera a seco; acabada esta operación se deja estar la pintura sobre la expresada superficie y mesa para hacer lo siguiente. Se clava sobre un bastidor de cuñas el lienzo crudo sobre el cual se ha de transportar la pintura, dejándole bien estirado, luego se empomiza para quitar los nudos o grujones que siempre suele tener el lienzo.

A la misma cola de engrudo que sirvió para encolar el papel sobre la pintura, sin necesidad de hacer otra nueva se añade una cantidad suficiente de cola fuerte, mezclando bien uno y otro al fuego, y cuando está fría se extiende con un cuchillo de imprimar lienzos [tachado] sobre el mencionado lienzo, pasando también una mano pero con mucha ligereza sobre el reverso de la pintura (esto es sobre la imprimación) y acto continuo se coloca la pintura por la parte mencionada sobre el lienzo nuevo que como ya se ha dicho tiene también la cola, y para que siente bien la pintura se pasará por encima la palma de la mano y en segunda se volverá el lienzo aplicando la pintura con el papel sobre la mencionada superficie a fin de sacar por los poros de la parte de atrás, la cola o engrudo sobrante, como se acostumbra a hacer cuando se forra un cuadro; hecha esta operación se deja secar tres o cuatro días, y cuando se nota que ya no hay humedad se pasa por encima del papel una esponja bañada en agua tibia para reblandecerlo y quitarlo fácilmente con los dedos. Cuando la pintura está enteramente descubierta se pasará por encima un par de veces la misma esponja bañada con agua más caliente para quitar enteramente el engrudo que puede haber quedado pegado en la superficie. Se enjuga bien con un lienzo suave y la operación queda hecha, dando a la pintura si se quiere una mano de barniz ${ }^{15}$.

De la venta de pinturas viejas y la oferta de las nuevas ya nos ocupamos anteriormente, lo mismo cabe decir del resto de la colgadura del

15 "Modos de transportar los cuadros pintados en tabla a un lienzo nuevo", en el Archivo General de Palacio (Madrid), Fernando VII, caja 24/12. 
gabinete compuesta de todo tipo de cuadros $^{16}$, cornucopias, urnas ${ }^{17}$, repisas de madera o cristal, adornos de vidrio ${ }^{18}$ y frisos, donde pintores, doradores ${ }^{19}$ y estuquistas desarrollaban una gran actividad (Vega 2000: 1821). Con respecto a los pintores quisiera recordar que se ofrecían para pintar "todo género de bosques, países, cabañas, monterías y cualquier pieza exquisita para adornar gabinetes en lienzo, en lámina de cristal o

${ }^{16}$ En los anuncios abundan las obras de temática religiosa en forma de cuadro (pintura, estampa, bordado, etc.) frente a una menor presencia de la escultura de bulto, realidad que también se refleja en la documentación de archivo que conservamos en la actualidad y que se extiende al resto del reino como se puede ver por el estudio del coleccionismo en la Sierra de Francia de Cea Gutiérrez (1993).

${ }^{17}$ Era muy habitual ofrecer urnas como las que siguen: "Se venden dos urnas, ricamente embutidas, que tienen una vara de alto con un cristal grande en la fachada y dos a los lados de media vara" (DN, 12. mayo. 1758); "Se venden dos urnas talladas, de una vara de alto y tres cuartas de ancho, con sus cristales correspondientes a todos lados, con el adorno de medias naranjas también con cristales, y dos cornucopias que se aseguran en el cuerpo de las urnas, dadas de azul, con las molduras y tallas doradas de fino, dará razón el maestro de coches que vive en la calle de la Salud" (DN, 17. febrero. 1759).

${ }^{18}$ Sirvan de muestra estos anuncios: "Dos catalanes que viven en la calle Hortaleza que trabajan adornos de vidrio" ( $D N, 22$. junio. 1759); "En la tienda donde se hacen ramos para las iglesias, plumas para señoras, \&c. que esta en la calle de Hortaleza frente de la casa de la Excelentísima señora duquesa de Fuenclara y junto a una platería, vive un sujeto que hace y vende con bastante conveniencia cosas muy exquisitas de vidrio como son frutas de todo género, flores, imágenes de hombres, animales, y finalmente de todo cuanto le pidan" ( $D N, 17$. enero. 1760).

${ }^{19}$ En estos años en los que hubo una verdadera profusión de dorados fueron también frecuentes los anuncios de quienes se prestaban a limpiar y devolver el lustre a esas superficies. Efectivamente los retablos se encontraban más deteriorados y sucios debido al humo de las velas. Entre los comunicados rescatamos los siguientes: «En la calle angosta de San Bernardo vive Bartolomé Orsimi, que tiene habilidad y un secreto, con el cual ofrece servir al público en beneficio de él como es limpiando cualquier retablo dorado, aunque esté muy negro de humo o por la humedad de las calles, dejándolo tan limpio como si se acabara de dorar" ( $D N$, 19. enero. 1760); "En la tienda de la plazuela de Herradores que hace esquina a la calle de las Hileras, inmediata a la de un ebanista vive un sujeto que tiene habilidad para limpiar todo género de cuadros dorados y sin dorar, limpia el oro de los retablos, aunque estén muy ahumados, dejándolos como nuevos, asimismo limpia la plata y el oro, sin quemarlo ni darlo con agua fuerte, todo lo cual hará en casa de los mismos dueños ( $D N, 13$. mayo. 1761); “En la calle del Reloj, entrando por la casa del Ilustrísimo señor Inquisidor General, segunda puerta de mano derecha, en el cuarto bajo, vive un sujeto que tiene habilidad para fabricar todo género de botones de oro, plata, metal dorado y plateado y también de estaño. Asimismo platea cualquiera pieza de metal, se limpia y reduce a toda perfección todo género de marcos antiguos dorados, retablos de iglesia, espejos, mesas y otras cosas dejándolo todo como si fuera nuevo y haciendo la posible conveniencian ( $D N, 6$. julio. 1761). 
en cualquier otra materia" ( $D N, 1$. julio. 1758); en gran medida esa pintura realzaba la chimenea, parte esencial de las habitaciones para cuyo servicio continuamente se anunciaban chismes, y creo que merece la pena tener presente que este tipo de pintura también la hizo el mismísimo Goya. Por otro lado, se sabe que los artífices de todos estos adornos domésticos eran muy activos en la venta de pinturas, propias y ajenas, y estaban en estrecha relación con los doradores, quienes se encargaban no sólo de enmarcarlas, sino también, en su mayoría, de la venta. No sabemos mucho sobre este tipo de comercio y hay personajes que probablemente tenían entre otras esta actividad; pensemos, por ejemplo, en Andrés del Peral, próspero dorador y charolista, que reunió una colección de pintura española de los siglos XVII y XviII quien, a la vista de lo expuesto, es posible que también comerciara con ella.

Hubo otros profesionales ebanistas, estuquistas y ensambladores que también prosperaron en estos años. Una de sus principales ocupaciones fue precisamente proyectar gabinetes, encargándose de transformar el espacio escénico donde luego se distribuía el resto del adorno. Entre otros comunicados, ya citamos en su momento el que insertó en el Diario Noticioso, el 5 de enero de 1767, José Soyé, maestro ensamblador de París, que vivía en la calle del Soldado - junto al cuartel de reales guardias Walonas-, ofreciéndose a dibujar y ejecutar "con primor todo género de obra de arquitectura en toda clase de maderas" [...] "sin tocar la fábrica y asegurando también las maderas con la mayor delicadeza, pudiéndose quitar y poner.

A partir de la estructura se diseñaba el adorno. El cliente podía imaginar cómo iba a resultar porque era posible visitar modelos o prototipos. Tal es el caso del estuquista de profesión Felipe Inza, padre del pintor de nombre Joaquín, en cuyo domicilio, sito en el segundo piso de la calle Atocha frente al Colegio de Loreto, se podía ver, a partir del 22 de abril de 1758 , en horario de 9 a 1 y de 4 hasta la puesta de sol, "el más apreciable y primoroso invento que se ha conocido hasta ahora, en cuanto al estuco para el adorno de gabinetes y salas". La obra, había sido aprobada por la Academia, institución cuyo dictamen hacía constar que era obra "permanente, lucida y hermosa" por estar labrada "sobre piedras, mármoles bruñidos, en cristales y todo género de materias frágiles o sólidas", pero, sobre todo, porque su fineza se sostenía en

el buen gusto y gravedad de la escultura, en bajos relieves muy delicados, pudiéndose prevenir desde hoy de este bello y precioso arte con la misma facilidad que de la pintura ${ }^{20}$ en el uso de adornos de toda especie y con la mayor majes-

${ }^{20}$ La venta de bajorrelieves también se registra, aunque debido a la posibilidad de ser enmarcados se ofrecían incluso como pintura: "Se vende una pintura muy exqui- 
tad y hermosura, porque siendo sobre tan preciosos campos y la escultura de relieve dorada de molido o de plata, se da a conocer por absolutamente agradable y seria.

Sabemos que Ynza fue el artífice del adorno del gabinete del marqués de Estepa con motivo de sus bodas y hay que suponer que encontró suficiente clientela, entre otras razones porque entre los servicios que prestaba se encontraba el del alquiler de "pinturas de todos géneros, guarnecidas con marcos dorados para que en cualquier hora se logre la comodidad de poder adornar una casa primorosamente.. El negocio del alquiler de adornos y mobiliario en el Madrid dieciochesco está por estudiar, aunque todo induce a pensar que era bastante activo y en algunos casos muy lucrativo, como el de la familia francesa Fourdinier, afincada en Madrid desde 1724 (Blanco Mozo 1998: 301-306). Se alquilaban adornos para los balcones de particulares con motivo de los festejos públicos ${ }^{21}$, las instituciones hacían lo propio cuando celebraban sus sesiones - tal era el caso de la Real Academia de Bellas Artes de San Fernando-, y los particulares podían disponer de todo tipo de objetos según sus necesidades como lo demuestra el repertorio que ofrecía la citada firma que estaba muy al día de la moda francesa (ibidem: 304).

En estos años, al igual que existían altareros, había también adornistas de gabinete (a veces eran los mismos), aunque parece que para algunos no resultó ser actividad muy lucrativa y hubieron de encontrar acomodo en otros empleos, quizá porque no eran imprescindibles si se quería tener un gabinete a la moda en casa, pues era posible comprarlo completo (Vega 2000: 14-15). Recordando cómo era el gabinete de la reina no extraña entonces que se vendieran fuentes artificiales y portátiles para su adorno ( $D N, 14$. junio. $1758 ; 31$. diciembre. 1760), todo tipo de pájaros con cantos diversos, "unos de flautilla, otros hablando y otros en su cán-

sita, de uno de los mas afamados autores, en talla, que representa la Adoración de los Santos Reyes que puede servir para un Oratorio o para una sala" ( $D N, 23$. junio. 1759); "Se vende una adorno de chimenea hecho de piedra mármol, hechura a la francesa, nuevo; y dos retratos con las imágenes de Jesús y María bajo de relieve de mármol de Génova con marco de jaspe muy exquisito" ( $D N, 2$. junio. 1760).

${ }^{21}$ "La persona que quisiera alquilar adornos para componer los balcones de la carrera acuda para tratar del ajuste a la calle del Niño, casa de Miguel Gómez, ciego, inmediato a la taberna" ( $D N, 12$. julio. 1760). Siete días después se vendían "los dos arcos triunfales que están el uno frente de la casa del Excelentísimo señor duque de Medina-Coeli, y el otro en la calle de las Carretas, enteros o por piezas: para tratar de ajuste se acudirá a la calle del Espejo a casa de Don Miguel Jiménez maestro adornista frente de un carpintero o a casa de José Ballina Maestro de obras que está en la calle del sordo". 
ticon $^{22}$, o toda suerte de animales disecados y embalsamados como, por ejemplo, los del escultor en marfil y piedra, discípulo de la Academia, Luis Enequín quien los preservaba además de "corrupción de polilla" y les daba una "bella postura natural. Uno de los pasatiempos del siglo era enseñar a cantar a los pájaros - pensemos en el retrato que hiciera Luis Paret de su esposa Micaela Fourdinier sentada en medio de un interior a la moda haciendo sonar un serinette-; la ambientación con jaulas de pájaros vivos o disecados, mezclada con adornos donde se mostraban figurados, hubo de tener fortuna si tenemos en cuenta que dominaron en el adorno del dormitorio del rey Carlos III (Herrero Carretero 2004); su hermano, el infante don Luis, disponía de un gabinete de pájaros (Tomé de la Vega 1998); el infante don Gabriel se rodeó de gran variedad de ellos, etc.

Completaban el adorno objetos diversos y curiosos, como un globo terrestre dorado a fuego o una aguja náutica ( $D N$, 9. julio. 1761); toda suerte de cosas exquisitas, todo tipo de espejos, cristales y vidrios; la Real Fábrica de Cristales de La Granja debía ser la gran suministradora, si bien hay que suponer que la prosperidad de este tipo de negocio fue la que llevó a cuatro oficiales de la misma a formar una compañía independiente $(D N, 17$. febrero. 1761).

No obstante, como decíamos anteriormente, había cierta afinidad entre el oratorio y el gabinete todavía en estos años, lo que explica que se ofertaran altares propios para uno u otro ( $D N, 24$. agosto. 1767), y todo tipo de retablos (aunque hay que tener presente que estos podían servir también para presentar ordenado el género en los comercios) ${ }^{23}$. Por esta

${ }^{22} \mathrm{El}$ repertorio era desde luego variado: "canarios, mixtos, de varias especies, gorriones de indias, ruiseñores, mirlos, tordos, maricas, calandrias, cuajadas y otras clases de pájaros" (Gaceta de Madrid, 16. febrero. 1751); existían también autómatas o ingenios de pájaros con sus cánticos (Varey 1995: 25).

${ }^{23}$ Sirvan de ejemplo estos anuncios: "En las vistillas de San Francisco [...] Antonio López dará razón de un sujeto que vende un retablo de talla, hecho según el orden compuesto y toscano, de alto vara y media y el ancho correspondiente; es bueno para una tienda lonja" ( $D N, 5$. julio. 1758); "Se venden dos retablos, los que se darán con bastante conveniencia para su ajuste se acudirá a la portería de San Cayetano" ( $D N$, 31. julio. 1760); "Se venden seis retablos de altar bien tratados y dorados, la persona que quisiere comprarlos acudirá a la tienda del carpintero de la calle Cedaceros" ( $D N$, 3. octubre. 1758); "En la calle de la Puebla, frente de la casa del Señor Marqués de Villa Real en un cuarto bajo que tiene dos rejas, se vende un retablo nuevo, una imagen de San Antonio de vara y media y otra de Santa Ana con varias cosas" ( $D N$, 27. enero. 1759); "Se venden tres retablos de talla, uno mayor Itodo dorado (aunque antiguo todo ello)], compuesto de cuatro columnas pequeñas [y pedestales] y su gradería, con seis láminas [de la vida de la Virgen] en la misma talla ya usado por lo 
razón no sorprende tanto que una urna con la Montaña de Montserrat "Con el Monasterio, Ermitas y al pie de la sierra una nuestra Señora de talla", pudiera encontrar acomodo en ambos (DN, 17. octubre. 1758) ${ }^{24}$. Ahora bien, a la vista de los anuncios, se comprueba que, por lo general, las obras de escultura tuvieron más dificultad que otro tipo de objetos para incorporarse al adorno del gabinete. La razón principal parece que es la temática: la mayor parte de la escultura es religiosa y, en los mismos anuncios, se oferta para oratorios domésticos, capillas e iglesias ${ }^{25}$, aunque también debieron encontrar buen acomodo en los dormitorios, donde era tradicional tener imágenes de devoción adornadas con aflores de seda, ramos de talco y arcos" y de "papel, canutillo de oro, plata" ( $D N$, 20 y 25 . marzo. 1758$)^{26}$; eran habituales las pilas para agua bendita y figu-

que se dará con bastante conveniencia, y se advierte, que se venderá separado el cascarón de cristales y las pinturas: los otros dos son más pequeños, el uno nuevo, de talla azul y dorado bueno para colocar cualquiera pintura regular, y el otro de talla dorada, también muy usado como el primero [...] para su ajuste se acudirá al Padre Rector del Hospital de Santa Catalina de los Donados" ( $D N, 23$. septiembre y 12. noviembre. 1761). Por último, la venta más singular que hemos encontrado es la siguiente: “En el convento de los padres recoletos (vulgo Copacavana) en el pilar que está frente del púlpito en el cuerpo de la iglesia se vende a voluntad de su dueño un retablo dorado y su sepultura correspondiente, sin cargo alguno, pues aunque hay dotación de nueve misas cantadas, las nueve festividades de la Virgen, corren de cuenta de la comunidad de dicho convento para cuyo fin tiene su fundación separadan, y el portero del marqués de Belgida era quien daba razón del precio $(D N, 3$. mayo, 1 y 27 agosto. 1760).

${ }^{24}$ Evidentemente los artífices trabajaban por igual para el ámbito religioso y civil: "En la calle de Bordadores, en la rinconada de la Casa profesa en el entresuelo de la casa de la señora marquesa de la Cueva viven dos sujetos de nación francesa y recién venidos de París que [...] hacen composición de mármoles muy exquisitos así para retablos como para mesas u otros adornos" ( $D N, 13$. julio. 1761).

25 "La persona que quisiere vender una imagen de san Francisco de Asís, o en su defecto la de san Isidro labrador, para colocarla en la iglesia parroquial de Santa Cruz de esta corte acuda para su ajuste en casa de Vicente Santos, frente de la Trinidad Calzada en el portal del cirujano, cuarto tercero" ( $D N, 27$. junio. 1767).

${ }^{26}$ La renovación en la decoración del resto de la casa también tuvo lugar y en lo que se refiere a los dormitorios la cama fue una pieza fundamental ya que, en función de ella, se organizaba el resto del adorno (recuérdese la que compró Goya para Martín Zapater). Entre los múltiples anuncios de todo tipo de objetos y mobiliario se puede destacar el siguiente: "Mr. Parisién de Nación francesa tiene habilidad para hacer toda suerte de camas, como son imperiales, a la duquesa, vandoma, baldaquín, en pabellón, a la turquesa, en túmulo y de reposo, también guarnece taburetes, sillas calesas y banquillos, hace camas con picadura a la última moda, remienda las tapicerías y las pone en su perfecto color y hacer adornos para iglesias, advirtiendo que ofrece ir a trabajar a donde fuere llamado [...] darán razón de este sujeto en la calle de Leganitos casa de madama Lemetre" ( $D N, 25$. junio. 1759). 
ras de santos a la cabecera de la cama $(D N, 15 \text {. septiembre. 1758 })^{27}$. Difícilmente podrían encontrar sitio en el gabinete un Cristo crucificado a pesar de su "hechura a la francesa" del que daba razón el batidor de oro Pedro Sánchez ( $D N$, 9. marzo. 1758), o el "retablo chico" en blanco con una imagen de la "Concepción y en medio de las gradas un crucifijo de bronce, hecho todo con diferentes molduras de talla y bronces y las gradas de espejuelos" ( $D N$, 11. marzo. 1758).

Fueron muy numerosos los oratorios completos, con su retablo y ornamentos ( $D N, 11$. enero. 1759), que se pusieron a la venta a mediados del siglo XVIII, pues, como ocurrió con los retablos y altares de las iglesias, también a ellos les alcanzó el cambio de gusto que supuso la llegada de la nueva dinastía. Como explica Tovar (1995: 86-87), a partir de 1730 se desarrollaba con rapidez una nueva corriente retablística fundada en modelos "cuyas raíces composicionales tienen una inspiración directa en una amplia tratadística basada en el Padre Pozzo y otros arquitectos italianos o franceses" muy directamente conectada con las novedades arquitectónicas que trajo la construcción del Palacio Nuevo y el mecenazgo real ${ }^{28}$. Uno de los casos más significativos fue el anuncio de la venta del altar mayor de la iglesia de San Antonio de los Portugueses ( $D N, 28$. mayo. 1762). Realizado entre 1631 y $1633^{29}$, era de madera dorada, con pinturas de Vicente

27 "La persona que quiera comprar un catre cofre con toda la ropa de cama y una Imagen de la Concepción en la cabecera acuda en el Real Sitio de Aranjuez" (DN, 6. julio. 1758).

${ }^{28}$ La renovación alcanzó también a los altares, tabernáculos y adornos: “En la prendería de la plazuela de Antón Martín, junto a la Capilla del Santísimo Cristo de la Salud darán razón de un sujeto, que vende un tabernáculo tallado y dorado por fuera y guarnecido de cristales por dentro que tiene una imagen de Nuestra Señora, pintada en tabla para reservar, con su pedestal de Ángeles para poner la custodia, como también un frontal de hoja de metal y otras 9 de diferentes colores, con ramos de oro y plata y algunos de buen uso por haber servido pocon ( $D N, 18$. octubre. 1758); "Quien quisiere comprar [...] un tabernáculo de concha guarnecido de bronces dorados a fuego" ( $D N, 15$. febrero. 1760); "Se vende un modelo del monumento de la catedral de Sevilla con su custodia dentro: demuestra en él las cinco ordenes de arquitectura, figuras, lámparas y serafines con 81 pies geométricos de alto sin el remate que tiene 12 pies" ( $D N, 22$. marzo. 1760); “Se venden tres adornos de altar en forma de medios puntos, guarnecidos de espejos, con sus molduras doradas y graderías correspondientes, los dos son iguales y el otro algo mayor" ( $D N, 24$. octubre. 1758); "Se venden dos adornos de altar, en forma de cascarón, guarnecidos de espejos, con las molduras doradas y gradas de lo mismo, tienen 4 varas menos cuarta de alto y 2 escasas de ancho" (DN, 27. marzo. 1759).

29 Pérez Sánchez (1995: 81) y Tovar (1995: 92) dicen que era obra de Juan Gómez de Mora, si bien en el catálogo de los retablos que figura en esa misma publicación (p. 298) consta que se hizo según las trazas de Miguel Tomás y Juan Garrido, y se 
Carducho y en el centro la estatua del santo con el Niño, obra del escultor portugués, afincado en Madrid, Manuel Pereira. Ponz (1947: 473) con satisfacción recoge expresamente el cambio que había tenido lugar:

El [altar] mayor se ha construido modernamente con diseño de Miguel Fernández habiendo dado el rey los mármoles y demás piedras. Consta de pilastras y de dos columnas de orden corintio, formando nicho en medio. A los lados del tabernáculo están dos ángeles en acto de adoración; sobre el cornisamento, niños con festones; y encima del arco de la capilla, el escudo de las armas reales. La mayor parte de la referida escultura es de don Francisco Gutiérrez.

El mismo camino siguieron el retablo viejo que se había quitado de la capilla del convento de Santa Bárbara ( $D N, 14$. septiembre. 1763), y los retablos colaterales de la capilla de la Virgen de Belén de la parroquia de San Sebastián sustituidos por otros nuevos (DN, 7. julio. 1766), cuyo adorno sería encargado a Ventura Rodríguez (Ponz 1947: 429). Ahora bien, a la vista de la documentación, parece que en realidad lo que se ponía a la venta era la estructura de madera mientras que pinturas y esculturas por lo general se conservaban, bien para incorporarlas al nuevo adorno, bien para distribuirlas en otras estancias. Por ejemplo, cuando se deshizo el retablo de Santa Bárbara, según testimonio de Ponz (1947: 478), las esculturas pasaron a incorporarse al retablo que proyectó el arquitecto Pedro Arnal junto con la estatua de la santa titular, obra de Isidro Carnicero, y las pinturas debidas a Carducho se distribuyeron "en diferentes sitios del conventon. En conclusión, como resume Marías (1995: 108), la madera dorada vino a ser sustituida por el mármol, los jaspes de colores y el bronce dorado, ay los maestros de arquitectura de retablos por los arquitectos titulados" porque a "este gusto más internacional y menos 'castizo' se unía un encendido deseo de renovación religiosa, reivindicando en términos de decoro, dignidad, seriedad y majestad los requisitos de la celebración del culto, y que debía afectar no sólo al estilo de los predicadores o a la arquitectura sino también al mobiliario de las iglesias".

En los domicilios se albergaban lọs altares y oratorios portátiles y estos fueron los que más salieron al mercado ${ }^{30}$. Estaban dedicados a un santo

doró por Francisco de Pineda en 1632. No se puso a la venta completo ya que cuatro de las pinturas de Carducho que formaban parte de él se conservan en la actualidad en la sacristía de la iglesia, y la imagen del santo pasó a formar parte del nuevo retablo.

${ }^{30}$ "En la calle de San Vicente, en una casa nueva que está inmediata a la del Señor Alcalde José Güell y Serra, cuarto principal, se vende un altar portátil con tres ornamentos diferentes para todo el tiempo del año y todo lo necesario para el adorno del altar es de plata" ( $D N, 1$. abril. 1761); "La persona que quisiere vender un 
o una virgen titular. Sirva de ejemplo el que se puso a la venta el 17 de mayo de 1758, dedicado a la Concepción, dorado y tallado que contaba con mesa de altar, frontal de hojalata y un cajón para ornamentos. Sabemos que los había nuevos y sin guarnecer ( $D N, 28$. agosto. 1760), o usados con el adorno completo ${ }^{31}$. Podían ser de hechura de cofre $(D N, 5$. diciembre. 1758) o de armario. Entre estos últimos destaca el que se anunció el 2 de julio y el 18 de septiembre de 1760 compuesto de:

gradería verde esmeralda, con los perfiles dorados; una imagen de Nuestra Señora de la Asunción de talla; doce candeleros encarnados [de madera] con los perfiles dorados; doce ramos plateados, con otras doce macetas [de madera] doradas; cuatro relicarios de talla dorados, con las repisas correspondientes; un frontal en lienzo pintura fina [al óleo] de varios [cuatro] colores [para los cuatro tiempos] con marco correspondiente a la gradería; un atril dado de encarnado y tarima ly dos repisas rinconeras]; todo está en un armario de madera de color de pórfido, insertos en él dos cajones.

Si Joaquín Inza invitaba a su casa para ver el efecto que causaba un gabinete, algo similar se hacía con los oratorios y, así, en la calle del Águila esquina a Calatravas, en casa de Diego Álvarez, maestro Adornista y Altarero, se colocó, el 17 de febrero de 1761, para que se pudiera contemplar su efecto, el oratorio portátil que se había puesto a la venta el día 14 del mes anterior. Que fueran portátiles no significa que fueran pequeños -éstos eran los conocidos como oratorios de camino o de cam-

oratorio portátil, de cualquiera hechura que sea, y también exquisito, medianamente primoroso, o inferior, acuda a casa del ebanista que vive en la carrera de San Jerónimo, frente de la Posada que llaman la Fontana de Oro, donde tiene encargo para tratar el asunto" ( $D N, 29$. septiembre. 1758); "La persona que tuviese para vender un oratorio portátil, decente, aunque no tenga recado ninguno para decir Misa, acuda para tratar de ajuste a la calle de la Abada, casa de don Manuel de Acebedo, que está frente del Molino de chocolate ( $D N, 22$. febrero. 1760). También hubo un mercado de ornamentos: "Se vende un cáliz y patena de oro guarnecido con multitud de esmeraldas para su ajuste se acudirá a casa de Don Francisco Montero, platero que vive en la calle Mayor portal de San Isidro, cuarto tercero" ( $D N, 28$. febrero. 1760); "Se vende un cáliz de oro del peso de cuarenta onzas y media esmaltado, con cuatrocientas treinta esmeraldas, para su ajuste se acudirá al padre sacristán mayor del convento de la Pasión de los Rr. PP. dominicos que está en la plazuela de la Cebada" ( $D N, 13$. junio. 1760); “La persona que tuviere un cáliz con algunos otros ornamentos de oratorio y quisiere deshacerse de todo..." ( $D N, 27$. julio. 1761).

${ }^{31}$ En ocasiones se vendían incompletos aunque esto pudiera significar el fracaso del negocio: “En la librería de la plazuela de Santo Domingo donde se vende el Diario, darán razón de su venta un Oratorio, el que habiéndose puesto el año pasado en el Diario, hubo varios sujetos que lo quisieron comprar lo que no ejecutaron por no darlo sin una lámina que tiene, el que se dará ahora ya sea con la dicha lámina o sin ella" (DN, 29. abril. 1761). 
paña algunos de los cuales también se ofertaron ( $D N, 23$. agosto. 1764). Prueba de ello es la detallada descripción que se dio del citado y, a través de ella, podemos hacernos una idea de cómo era el gusto que se desarrollaba en estos espacios domésticos y el marco en el que acababan integrándose muchas de las esculturas y ornamentos que circularon en estos años. Era como sigue:

Dado de charol azul por dentro y fuera con sus molduras talladas, y doradas y el herraje también dorado, con su cajón grande y alacenas debajo para los ornamentos, ramilletes \&c. tiene por titular a nuestra Señora de la Soledad ${ }^{32}$, en pintura, de tres cuartas de alto y lo correspondiente de ancho con su cristal y talla dorada, tiene a los lados dos efigies de bulto de a tercia de alto, la una de San Antonio de Padua y la otra de San Félix de Cantalicio, con sus repisas y doseles uno y otro tallado y dorado, y desde la Mesa Altar, hasta la pintura de nuestra señora tiene tres Gradas y dos estípites, y en los testeros de los lados otras dos pinturas, de tres cuartas de alto y lo correspondiente de ancho, la una de Santa Gertrudis y la otra de Santa Rita ambas con sus cristales y repisas talladas y doradas.

Para su adorno tiene dentro una Santísimo Cristo hecho de plata con sus cantoneras y a los pies su Madre Santísima, San Juan y una Calavera de lo mismo, en una Cruz de ébano, con su peana de lo mismo todo de dos tercias de alto. Una imagen de nuestra Señora de Copacavana de plata de una tercia de alto. Otra de nuestra Señora de la Concepción de piedra de alabastro con su peana afiligranada de lo mismo de media vara de alto.

Varios ramilletes con sus macetas de metal blanco. Varios candeleros de lo mismo. Para Ornamentos, tiene un cáliz de plata sobredorado y cincelado, con patena y cucharilla de lo mismo. Unas vinajeras, platillo y campanilla de plata. Un misal nuevo con su atril de charol. Una casulla con estola, manípulo, paño de Cáliz, bolsa de Corporales y frontal de media persiana encarnada y matizada en blanco con su forro de tafetán y galón de seda. Otra casulla con las mismas piezas correspondientes de damasco morado y verde. Dos cíngulos de seda. Dos amitos con sus encajes finos. Un alba de lienzo Imperial con encaje y randas. Y dos sabanillas de lienzo fino también con su encaje.

${ }^{32}$ Como puso en evidencia Elena Sánchez de Madariaga en la ponencia "La Virgen de la Soledad: la difusión de un culto en el Madrid barrocon, presentada en el Coloquio Internacional sobre "Usos y espacios de la imagen religiosa en la Monarquía Hispánica del siglo XVII" (Casa de Velázquez, Madrid, 7-9 de febrero de 2005), durante el siglo xviI el culto a esta advocación de la Virgen se popularizó dando lugar a la proliferación de imágenes y hermandades, de manera que era fácil encontrar una efigie en lugares públicos - portales, mesones, posadas, etc.—, a los que se sumaría la devoción privada en el ámbito doméstico y eclesiástico: “Con motivo de estarse reedificando parte de la iglesia de los PP. Premostratenses de esta corte, y hacerse dicha obra a expensas de las limosnas de los fieles, por la mucha pobreza en que dicha comunidad vive, se pone en noticia del público, que la capilla de la Imagen de nuestra Señora de la Soledad se halla sin Patrono, por lo que si hubiese sujeto que quiera admitir y entrar en dicho patronato acuda al Rmo. P. Abad de dicho convento para tratar de este asunto" ( $D N, 20$. abril. 1759); del mismo modo se dio a conocer la venta del patronato de algunas otras capillas de la reedificada iglesia ( $D N, 31$. julio. 1761). 
El mobiliario propio del oratorio era el formado por reclinatorios, 'pridiu' o humilladeros que, como era de esperar, podían ser a la moda de Francia o Inglaterra ( $D N$ 22. febrero. 1759), siempre se anunciaban por ser de calidad o primorosos y, en algunas ocasiones, se describieron con detalle; sirva de ejemplo el anunció que puso el ebanista establecido en la calle Mayor para la venta de "cuatro humilladeros, cubiertos de ébano, y palo santo, con columnas salomónicas, arquitas en las tarimas, almohadas y con atriles encima" ( $D N 29$. marzo. 1759). Finalmente, añadiremos que existía otro tipo de objetos con destino a estos espacios devocionales, como por ejemplo las arquillas o arquetas, centro de los Monumentos del Jueves Santo, a veces muy elaboradas: "El ebanista que está en la calle de los Preciados ${ }^{33}$, cerca de la Puerta del Sol, vende un Arca para colocar el Santísimo en el día de Jueves Santo, que tiene una vara de alto, con cristales y figuras de bronce, doradas de molido" ( $D N, 7$ febrero 1760); "En la calle Mayor, casa del ebanista que está pasada la del Exmo. Sr. conde de Oñate, se venden dos Arcas buenas para colocar el Santísimo el día de Jueves o Viernes Santo, la una cubierta de ébano con las molduras y todo lo demás fingido de plata de buena idea y con gradilla, y la otra está hecha en Indias, cubierta de marfil y pintada en vidrio" (DN, 18 marzo 1760).

No hay espacio para hacer un recuento de todas las ofertas de escultura, arte sobre cuya antigüedad se publicó un artículo en el periódico (29 y 30 de marzo de 1759) ${ }^{34}$. No obstante, es posible hacer un esbozo de la procedencia, tipología y temática de lo que circuló en aquellos años teniendo muy presente que muchas de las esculturas de bulto debían adquirirse progresivamente para adornar el oratorio, bien porque se de-

33 Este mismo ebanista sabía "de un Arca que puede servir para colocar al Santísimo Sacramento el Jueves Santo, lo venderá su dueño a cualquier parroquia, comunidad o particular que quiera dejar esta alhaja por su memoria, advirtiendo que la mayor parte de su valor la admitirá en sufragios de $\operatorname{Misas}^{\prime}$ ( $D N, 16$. febrero.1758 y 16. enero. 1761).

${ }^{34}$ Entre otras noticias curiosas en relación con la escultura en el periódico se pueden citar los anuncios del 2 de septiembre de 1758 por el que "un joven de poca edad desea acomodarse para aprender el Arte de Escultor, darán razón en la callejuela del Clavel sin salida, junto a San Martín, en la última casa cuarto últimon; y el del día 5 de marzo de 1760: "Un joven de edad de 18 años desea acomodarse en casa de algún escultor o tallista de cuyo oficio tiene muy buenos principios como se puede ver por algunas obras que tiene hechas de su mano en su misma casa, darán razón en casa de don Pedro Grafrertes procurador de los Reales Consejos, que está en la calle del Juanelo". Tampoco se refleja bien en los anuncios toda la pequeña escultura que adornaba los muebles como la papelera que tenía "arriba figurada toda la Historia de Adán Corpóreo, de escultura" (DN, 16. septiembre. 1758). 
mandaba a través de las páginas del periódico, bien porque se ofertaban en ellas ${ }^{35}$. Así se dieron comunicados donde se anunciaba la venta de esculturas junto a otro tipo de objetos diversos. Entre ellos es representativo el que se publicó el 1 de marzo de 1760:

Se venden [...] diferentes imágenes de talla, como son San Joaquín, Santa Ana y la Virgen Nuestra Señora, San José, y el Niño Dios, San Nicolás de Bari, Santa Teresa, San Fernando, y un Niño, todas de diferentes tamaños; asimismo una Nuestra Señora, San José y el Niño hechos de marfil, de una tercia de alto, una Nuestra Señora de la Concepción hecha también de marfil, que tiene otra tercia de alto, una pintura en tabla que tiene una vara de alto y tres cuartas de ancho, la cual representa la imagen de San Juan Bautista hecha en la Escuela de Rafael, una silla de manos de toda moda con forro de terciopelo de varios colores, toda la talla dorada y en las tarjetas pintados varios países, para su ajuste se acudirá a casa de Valentín Díaz ebanista que está en la calle de las Veneras, junto a las casas del Señor Conde de Alcolea que en todo se hará la mayor equidad.

Hemos encontrado algún anuncio de hechura a lo antiguo pero no son muy frecuentes ${ }^{36}$. Por el contrario, lo primero que salta a la vista es

${ }^{35}$ "La persona que tenga alguna Efigie de bulto de San Juan Bautista de media vara de alta con Corderito y Cruz y quisiere por su justo precio privarse de ella acudirá para su ajuste a don Agustín Collada capellán de las Monjas carmelitas de Santa Ana de esta Corte" ( $D N$, 15. abril. 1758); "En la calle de San Juan entrando por la plazuela de Antón Martín primer portal a mano izquierda al cuarto segundo asiste un caballero que desea hallar una buena efigie de talla de san Antonio Abad de media vara, cuando más tres cuartas de alto, advierte que su residencia en esta corte no será más que 4 o 5 días" ( $D N$, 12. junio. 1758); "En la Puerta del Sol a la entrada de la calle del Arenal en el taller del Ebanista se venden [...] una imagen de talla que representa el misterio de la Concepción de Nuestra Señora, otra de san Antonio de Padua, otra de santa Teresa y otra de san Pedro Alcándara, se advierte son muy oportunas para una iglesia u oratorio" ( $D N, 20$. junio. 1758); "Se vende una efigie de un Santísimo Cristo de arquitectura hecha de piedra de alabastro la cruz y el canto guarnecido de piedra de ágata oriental. Para su ajuste se acudirá al Sacristán Mayor del Refugio" ( $D N$, 18. junio. 1760); "Se vende una imagen de santa Bárbara nueva, de altura poco menos de dos varas, la que se dará con bastante conveniencia, es muy a propósito para cualquiera iglesia o retablo aunque sea grande, para su ajuste se acudirá a la calle de San Ildefonso, frente calle de Atocha, cuarto bajo de la casa de la parra" ( $D N$, 26. marzo. 1761); "La persona que quisiere comprar la hechura de una imagen de Nuestra Señora de la Concepción de talla de medio cuerpo con su urna o caja de cristales de Venecia y mesilla para su asiento, acuda para tratar de ajuste a la calle del Comillo casa que hace esquina a la de Fuencarral frente de una taberna cuarto bajo" ( $D N, 29$. julio. 1761); "En la calle de las Tabernillas de San Francisco, encima de un taconero, necesitan de una efigie de san José con el Niño Dios que tenga cerca de cinco cuartas de altura, la persona que la tuviere y quisiere deshacerse de ella acuda para tratar de ajuste al cuarto principal de aquella casa" (DN, 13. abril. 1761).

36 "Se vende una Imagen pequeña de San Juan hecha de talla a lo antiguo que tiene una vara de largo, para su ajuste se acudirá a la Aguardentería que hace esquina a la calle del Olivo" ( $D N, 14$. agosto. 1758). 
la continua llegada de figuras de Nápoles que estaban de moda. Una de las razones de su éxito fue su carácter pictórico, no en vano pintores de tanto éxito en Madrid como Lucas Jordán o Francesco Solimena tuvieron gran influencia en el desarrollo de la escultura de la primera mitad del siglo xviII. Su naturalismo, sencillez, ligereza, elegancia, luminosidad, expresividad, movimiento y dulzura encajaban perfectamente en la composición de adornos de estuco; mientras que la emotividad que caracterizaba a la escultura en madera de maestros como Michelle Trillocco o Nicola Fumo hizo que fueran sus modelos los que tuvieran éxito entre la escultura devocional, un tipo de escultura que Ciechanowiecki (1990: 49) califica de 'popular' porque gustaba por igual a las gentes urbanas y paisanas, a nobles y plebeyos. Tanto es así que a las que llegaban de fuera se sumaban aquellas que las imitaban de producción local: por ejemplo, el 13 de diciembre de 1758 se anunciaban afiguras sueltas de todos géneros y tamaños para adornos de oratorios y gabinetes, su hechura y colorido no es menos primoroso y de gusto que las fabricadas en Roma $O$ Nápoles".

Aunque las había de temas profanos, la mayoría de las que se dio noticia eran de asunto religioso: santos, vírgenes, cristos y niños, cuyo destino podía ser el oratorio y los dormitorios, aunque algunos eran buenos para iglesias y capillas. Por supuesto que hubo oratorios completos de Nápoles $y$, por el tipo de figuras que los adornaban, se puede incluso pensar que se hicieron ex-profeso para ser vendidos en Madrid: por ejemplo el portátil "de tres varas y media de alto, dos y media de ancho y más de una vara de fondo con gradas, mesa de altar, frontal, algunas flores de mano y diferentes hechuras de bulto, legítimas de Nápoles entre las cuales se halla la de San Isidro Labrador y Santa María de la Cabeża" (DN, 16. mayo. 1758).

Lo que más abundaba eran, como cabía esperar, las figuras de niños ${ }^{37}$ dada su versatilidad para las prácticas devocionales y lúdicas tanto infantiles como femeninas, y sus posibilidades al ser imágenes vestideras cuyo guardarropa en muchas ocasiones además de rico no tenía carácter religioso alguno. Teniendo en cuenta que el origen de estas figuras había

${ }^{37}$ De nuevo es relevante el número de este tipo de imágenes que figura en la documentación histórica de la Sierra de Francia (Cea Gutiérrez 1993), de los doce registrados entre 1704 y 1782, dos eran pintados y el resto de bulto; incluso actualmente se conservan bastantes en Mogarraz, Cepeda y La Alberca "donde reciben el cariñoso apelativo de 'Batuecos' o 'Niños Batuecos' porque atribuyen su procedencia a ese desierto de carmelitas de donde los subieron los frailes cuando la desamortización de Mendizábal" (Cea Gutiérrez 1992: 64). 
estado en Italia ${ }^{38}$, entre los anuncios se podían encontrar figuras de niños legítimos ( $D N, 23$. noviembre. 1762), aunque también había de imitación en pasta $(D N, 10$. junio. 1761) o los que hacía en cera pintada fray Pedro Cano Machuca, religioso lego del Real Convento de la Trinidad Calzada de la Ciudad de Córdoba ( $D N, 13$. abril. 1758). En esto también se ve la influencia napolitana, ya que precisamente la escultura en pasta, es decir en porcelana, y en cera coloreada llegó a su máximo esplendor durante el reinado de Carlos de Borbón, el futuro Carlos III de España. La difícil conservación y falta de aprecio, unida a la temática de las piezas conservadas - principalmente religiosa - ha hecho que las ceras, como afirma Praz (2004: 220), no estén consideradas "como un arte en el sentido estricto de la palabra. No son objetos artísticos, sino curiosidades", debido en gran parte a la "decadencia a la que la materia de este arte se halla especialmente sometida, desvaimiento y oscurecimiento, mutilación y polvo" que hace que resulten "a menudo repelentes" (ibidem: 222). No obstante, fueron objetos que encontraron lugares destacados en los gabinetes de los príncipes de toda Europa desde el Renacimiento, momento en el cual se vinculan con el arte de la pintura, siendo uno de los medios más aptos para crear cuadros tridimensionales o reproducir en tres dimensiones otros célebres ${ }^{39}$. De todas formas parece que en España fue una actividad muy relacionada con la vida conventual pues el prestigiado, por sus pequeñas figuras y grupos, Eugenio Gutiérrez de Torices fue fraile mercedario quien, como apunta Urrea (1979: 494), pudo ser el maestro de José Calleja, otro artífice que alcanzó cierta fama. Así el 7 de febrero de 1758 se daba este comunicado: "se venden cuatro figuras pequeñas de cera que representan otros tantos Pastores y se dice son trabajo del primoroso Callejo, están colocadas en sus nichos, con adornos de cristal

\footnotetext{
${ }^{38}$ Sobre este tema es fundamental el capítulo "Holy Dolls: Play and Piety in Florence in the Quattrocento" de Klapisch-Zuber (1985: 310-329), donde además de preocuparse del origen de este tipo de esculturas y de su fortuna en el ámbito doméstico y conventual femenino, profundiza sobre los usos y prácticas devocionales.

39 Todavía en el siglo xIx era ésta una actividad que gozaba del favor del público y prueba de ello es que en las galerías de cera se reproducían al tamaño natural cuadros célebres como La campana de Huesca de Casado del Alisal premiado en la exposición de Bellas Artes de 1881 y Doña Juana la Loca de Pradilla premiado en el mismo certamen pero del año 1878 , que se expusieron en la "Gran galería de figuras de cera y museo anatómico manual " de Zaragoza, situada en la calle del Coso, en 1882 y 1883 respectivamente (Sánchez Vidal 1994: 114-117). Curiosamente el zaragozano Juan Revenga (h. 1614-h. 1684) fue uno de los introductores de este arte en la corte pues, según Palomino (1947: 1015), se "socorría de hacer cosas de cera para urnas, cajones y escaparates [...] con tan extremado primor que desmentía el natural.
} 
a la Romana ${ }^{40}$. En cera se hacían nacimientos ${ }^{41}$, escaparates que fueron muy abundantes en España (Urrea 1979; Estella 1993), láminas pintadas y hechuras de santos adornadas como las "dos urnas pequeñas que tienen cada una tercia de alto y media vara de largo hechas de pino y acharoladas con cuatro cristales cada una y dentro tiene la imagen de santo Justo y la de san Pastor hechas de cera, con sus fruteros" $(D N, 5 \text { mayo 1760 })^{42}$.

Los niños se vendían sueltos ${ }^{43} \mathrm{o}$ por parejas ${ }^{44}$, independientes, solían ser de talla con sus urnas y mesas, o con peana a la moda y haciendo juego (en muchas ocasiones enriquecidas con embutidos de distintas maderas o de hueso). Entre los múltiples anuncios destaca el que se publicó el 5 de mayo de 1760 y es como sigue:

Se venden dos hechuras de talla, la una con la imagen de san Juan y la otra con la del Niño Dios, hechura de Nápoles con las peanas doradas, los vestidos de encajes con sus pelucas y sombreros que tiene tres cuartas de alto [...] se acudirá a casa de Andrés Suárez escribano real que vive frente de los santos del Convento de nuestro P. S. Francisco de la Atahona en un cuarto bajo.

En su mayoría eran Niños de Pasión con las correspondientes ainsignias" y san Juanitos con el cordero, aunque los había singulares como el "Jesús sentado en un trono de querubines" y el "San Juan sentado en el peñasco" ( $D N, 12$. noviembre. 1760), y, quizás por esta razón, se añadía que estaban tasados en 1.200 rs. cada uno. Se publicaron algunos otros precios como la hechura de Santa María Magdalena y la de San Jerónimo, tasadas en 6.000 reales ( $D N, 3$. mayo. 1758), la Virgen del tamaño

\footnotetext{
${ }^{40}$ En 1722 había en casa de los duques de Osuna "dos urnas de concha y nogal con sus cristales y en ellos una santa Teresa, de cera, de mano de Calleja, en actitud de escribir y un San Antonio de Padua" y dos urnas con la misma temática se conservan actualmente en el Monasterio de la Encarnación de Madrid (Urrea 1979: 494).

${ }^{41}$ "Se vende una urna, con su mesa correspondiente de peral, tiene 6 cristales grandes de fachada y 7 chicos con cenefa, 18 vidrios ordinarios por los lados con cenefa de la misma madera tallada, y dentro tiene un Nacimiento de figuras finas de cera" ( $D N, 2$. julio y 24. diciembre, 1760); véase también Estella (1993: 160).

${ }^{42}$ La presencia de niños de cera en España se remonta a las colecciones reales ya en el siglo xvi y la moda se extendió pronto entre los particulares, por ejemplo en el testamento de Calderón de la Barca de 1681 figuran "dos niños de cera" (Estella 1993: 152).

${ }^{43}$ "Se venden [...] una efigie de un Niño Jesus [en pie y bien tratada], muy primorosa y embarnizada de nuevo, con su peana de talla dorada, otra efigie de Santiago hecha de piedra de alabastro, con peana de lo mismo de cuarta y media de alton (DN, 18. septiembre. 1761).

${ }^{44}$ El 29 de enero de 1760 se anunciaba la venta de "cinco niños de Nápoles y entre ellos un Niño de Pasión.
} 
de 3 a 4 cuartas y obra "de un grande autor" que fue tasada en 1.400 ( $D N$, 18. julio. 1758), o las "dos imágenes, la una de Nuestro Señor de la Humildad, la otra de Nuestra Señora de los Dolores con sus urnas muy primorosas de cristal, tasadas en 60.000 reales y se darán por 14.000 " ( $D N$, 8. abril. 1762). Es posible que fueran las mismas que se anunciaban el 5 de diciembre de 1758, pero en esta ocasión se decía hecha por "uno de los famosos autores napolitanos", y es que tampoco se dio mucha información sobre los artífices ${ }^{45}$; por eso destaca el san Francisco Javier de tres cuartas y media de alto que era obra de "Nicolás Fum" (Nicola Fumo), que vendía el ebanista que vivía en la calle de Baño $(D N, 20$. octubre. 1758), y que nos da una pista de cómo era la escultura que se ofertaba ${ }^{46}$. En fin, había toda suerte de santos que eran de este gusto, como santa Teresa y San Antonio ( $D N, 13$. diciembre. 1758), san Pedro de Alcántara (DN, 30. abril. 1759), etc.

Dentro de esta producción napolitana o de imitación hay que citar lógicamente los nacimientos que se abrían en locales públicos o se organizaban en domicilios particulares, especialmente se recomendaban en aquellos donde había niños, y encontraban cabida por igual en oratorios y gabinetes porque eran más expresión del gusto por el espectáculo y el teatro de la época - los había que eran una demostración de la habilidad en la construcción de autómatas ${ }^{47}$ - que de un sentimiento religioso, y podían adecuarse a los distintos gustos según fuera el estilo de sus figuras: más pictórico, por tanto más propio para el gabinete, o más del tipo de la escultura de talla, que se acomodaría mejor al oratorio. Como explica Causa (1990: 295), este Belén dieciochesco es el Belén cortesano, diferenciado claramente de aquél de iglesia que durante siglos había servido para las funciones litúrgicas como un instrumento de refuerzo de la fe. A través de sus pequeñas figuras "revela una experiencia mundana, sustancialmente desencantada y laica, juego a la moda de la corte, de la nobleza y de los burgueses ricos; es belén palaciego, hobby; ocio de élite

${ }^{45}$ El 5 de septiembre y el 17 de noviembre de 1758 se comunicaba que estaba a la venta una efigie de san Juan de bulto, hecha por uno de los académicos de las tres bellas artes de mucha habilidad.

${ }^{46}$ Sobre el rastreo de la obra de este escultor en España véase Estella (1976).

47 "La persona que quisiere ver una Nacimiento muy primoroso, con todas las figuras de movimiento acuda a la casa del señor marqués de la Olmeda que está en la calle de Jacometrezo entrando por la plazuela de Santo Domingo, primera puerta de mano izquierda cuarto bajo, previniéndose que desde el día 24 en adelante lo dejaran ver a todas horas dando un real de vellón cada persona" ( $D N, 22$. diciembre. 1761). Sobre la venta de nacimientos y los espectáculos que se abrían con este motivo véase Varey (1995). 
al que se atiende en las horas ociosas del día. También eran juguetes, porque sobre las figuritas era fácil intervenir dándoles nuevas posturas, modificando el personaje intercambiando los atributos o cambiándoles los atavíos. A esto se sumaba la diversidad de flora y fauna, obra de los especialistas, animalisti y finimenti, y la sensibilidad con la que se distribuían las figuras según un guión variable libremente inspirado en la historia evangélica donde también se hacían eco de los acontecimientos de actualidad - fiestas reales, llegada de embajadores exóticos, etc.-, para atraer la curiosidad del ciudadano.

El nacimiento era una ocupación en la que se distraía lo más granado de la sociedad, al mismísimo Carlos III gustaba ver a su esposa, María Amalia de Sajonia, cosiendo vestiditos para las figuras y él se divertía amasando y cociendo pequeños ladrillos, colocando los corchos de la escenografía, haciendo una cabaña para pastores, o colocando los deco$\operatorname{rados}^{48}$. Así, como concluye Causa (1990: 296), era ante todo "ostentación, certamen, afirmación personal" que no todos podían permitirse.

Por la rifa que se hizo en el Convento de Carmelitas Descalzas, anunciada el 26 de agosto de 1758, sabemos que un nacimiento de Nápoles de ciento cincuenta y ocho figuras con sus trajes, "vestidas a lo natural", y adornos correspondientes fue "tasado por sujeto hábil en la Escultura en 54.785 rs. vellón"; aunque los había mucho más económicos, como el de figuras de a tercia que se componía de "misterio, dos ángeles, los reyes, veinte hombres, ocho mujeres, buey y mula del misterio, cinco bueyes grandes, cuatro ternerillos, doce ovejas, doce cabras, un macho de carga, tres camellos, caballos, dos perros" y "algo deslucidas otras nueve figuras", que se tasó en 9.500 reales ( $D N, 23$. noviembre. 1765).

Cuando se acercaba el periodo de Navidad eran muy frecuentes los anuncios de nacimientos ${ }^{49} \mathrm{y}$, puesto que los que más abundaron fueron los de barro - los más raros fueron los de cera-, cabe suponer que en más de una ocasión fueran sustituidos por los napolitanos a la moda. Efectivamente se podían comprar figuras sueltas de barro cocido ${ }^{50}$, algu-

${ }^{48}$ Como es sabido cuando Carlos III vino a reinar a España se trajo un magnífico Belén de Nápoles que siguió ampliándose hasta la época de Carlos IV; no obstante no fue el primero, ya que Felipe $\mathrm{V}$ en su viaje a Italia fue obsequiado con uno y se lo trajo a Madrid (Herrero Sanz 1998).

49 "Se vende un nacimiento de perspectiva muy vistoso" ( $D N, 18$. diciembre. 1758).

${ }^{50}$ "Frente de la esquina de la calle del Correo, en el puesto de Libros de José Amposta se venden diferentes figuras de barro cocido muy primorosas para nacimientos" (DN, 31. mayo. 1759). 
nas procedentes de Bruselas y París ( $D N$, 4. junio. 1764), aunque las más comunes eran las que venían de Granada y Sevilla (tanto de nacimientos como de santos sueltos) $)^{51}$, pero fueron también muy abundantes los que se ofertaron completos como el que tenía el "ebanista que vive en la calle Mayor mas allá del Parte, vende con mucha equidad un Nacimiento que se compone de 15 misterios, hechos de barro, con templos, portal de Belén y palacios de madera" ( $D N, 2$. diciembre. 1758). La diferencia de precio con los de producción nacional la podemos evaluar al comprobar que eran 8.000 reales los que se pedían por un

Nacimiento grande, compuesto de cerca de 500 figuras de barro, muy exquisitas, chicas y grandes, hechas de una misma mano, no con molde, sino es a pulso, se compone del Misterio, muy adornado de ángeles y otras curiosidades, portal de madera, tejado de lo mismo y pilares, un pastor y una pastora con ofrendas en adoración, reyes en viaje, otros en adoración a pie, cueva de la Anunciación con las figuras en distintas posturas, varios pastores y pastoras, con diferentes posturas y ofertas, una torada con cabestros y terneros, que ésta se lleva la mayor atención por lo exquisita y dispuesta, hay un bosque donde se colocan varios animales como son leones, tigres, jabalís, osos, zorras, monas, ciervos, venados, gatos y lobos, hay mucha variedad de ovejas, carneros, chotillos, cabras, perros y burra de ato, que todo se coloca por el casco, a la mejor idea tiene un bosque compuesto de liebres, conejos y perdices, tiene ciudad con palacio, arrabales, castillos y muralla, que sobre estas se colocan soldados que la guarnece y otras varias curiosidades, con sus peñascos, que se componen de 4 pedazos en cuchillo que unidos parece todo uno ( $D N, 20$. noviembre. 1760).

Dos mil reales menos se pedían según el siguiente anuncio por uno bastante similar:

Se vende un nacimiento grande, compuesto de cerca de quinientas figuras de barro $\mathrm{y}$ alambres en las articulaciones para mayor fortaleza, grandes y pequeñas con variedad de animalillos [...] con sus caminos, subidas y bajadas para la pastorela [...] como también diversas cosas de diversión y todo muy propio al misterio que representan. Es obra digna de cualquiera Caballero mayormente si tuviera niños.

51 "En la calle de los Preciados, frente de donde estuvo el Correo de Toledo, en una joyería se venden con mucha equidad varias figuras para Nacimiento y diferentes efigies de santos todo de barro cocido de Granada" ( $D N, 28$. noviembre. 1758); "En la tercera tienda de las covachuelas de san Felipe el Real viniendo por el Correo, darán razón de un sujeto que vende un nacimiento con figuras de barro de Sevilla, compuesto de tres trozos de peñascos pintados al óleo, con el Portal de talla, y una Gloria de Ángeles tocando todo género de instrumentos, elevación, etc. bueno para un Oratorio o Gabinete" ( $D N, 24$. noviembre. 1760); y en esta misma tienda se vendían "cien piezas de figuras y ganado hechas de barro en Sevilla buenas para nacimiento y entre ellas, los misterios necesarios, las que se darán sueltas o separadas" $(D N, 11$. diciembre. 1760). 
Su tasa es de 6.000 rs. y se dará con mucha equidad en la Botica que está junto a la fuente de Relatores ( $D N, 2$. diciembre. 1761).

Vistoso debía ser también el que se ofreció nueve días más tarde aunque no sabemos el precio:

Se vende un nacimiento de figuras de barro, fabricadas en esta corte, de a tercia de alto y el misterio de media vara, hecho todo del mejor autor que se ha conocido, tiene reyes a caballo, camellos, Guía y Tumbalero, compuesto de cien piezas sin el ganado de corderos, cabras y aves, tiene Casa de la Virgen hecha de madera, palacio del rey, cuatro mesones, puente, ciudad de perspectiva y portal de lo mismo, para su ajuste se acudirá a la tercera covachuela de San Felipe el Real, entrando por la Puerta del Sol.

En relación con las figuras del nacimiento y su puesta en escena debemos hablar de otros objetos singulares: las casas de muñecas cuyos habitantes eran personajes de la infancia de Jesús. Contaban con toda suerte de detalles en cuanto a figuras y mobiliario. El 13 de diciembre de 1762 se ponía a la venta

una Casa de la Virgen de dos varas de largo, hecha de madera, adornada de china y azófar la cocina, con su taller del señor san José y demás figuras que corresponden muy exquisito. Un palacio del Rey Herodes del mismo tamaño que la Casa muy especial y con las figuras también que corresponden al Misterio. Una Casa del Misterio cuando fue escogido san José por Esposo de nuestra Señora con todos los varones que se hallaron. Una casa del Misterio de los desposorios de San José, con las figuras correspondientes. Un templo del Misterio de la Circuncisión con el Viejo Simeón y demás figuras. La Casa del Misterio de la visitación con todas las figuras correspondientes, un templo del misterio cuando el Niño Dios estaba disputando con los doctores.

Eran muy comunes las obras de escultura que iban guardadas en escaparates $^{52}$, o en urnas de madera lisa (peral, pino, cedro, ébano, palo de santo, finas de indias, etc.) o embutida y con cristales, siendo muy ponderadas aquellas en las que el cristal del frente era de una sola pie-

52 "Se venden dos escaparates grandes de charol encarnado y talla dorada con un espejo encima, tiene cada uno 15 cristales de fachada de cuarta y media y en los costados 20 cada uno, el uno tiene dentro un nacimiento con varias figuras de barro; el otro tiene una imagen de Santa Rosa en medio de una marina, tiene cada uno de alto tres varas y media con mesa escaparate y copete, para su ajuste se acudirá a la calle del Pez casa del mismo nombre, cuarto bajo donde vive un dorador" (DN, 21. noviembre y 3 . diciembre, 1760). En cuanto a la diferencia entre caja y escaparate, la primera "tenía forma rectangular con su vidriera y portezuelas", mientras que el segundo tenía "todas sus paredes de cristal y a veces cubierta a cuatro aguas, también vidriadas. Su contenido no era necesariamente religioso sino que podían tener pasajes considerados fútiles" (Cea Gutiérrez 1992: 63). 
za. En esta especie de vitrinas se podían colocar figuras de muy diversos materiales: de marfil se anunciaron una crucifixión completa (Cristo con los atributos de la Pasión y la Virgen, san Juan, la Magdalena y varios ángeles, $D N, 20$. mayo. 1758), o nacimientos ( $D N, 20$. mayo. 1758); en cristal se ofertó la vida de Cristo ( $D N, 30$. junio. 1758); en cristal y esmalte los misterios del Nacimiento, Oración en el Huerto y Monte Calvario ( $D N$, 26. enero. 1760); talladas en madera eran probablemente el resto, como las efigies de san Antonio ( $D N$, 4. abril. 1758), santa Teresa ( $D N$, 20 y 31. mayo. 1758), el arcángel san Miguel ( $D N, 31$. mayo. 1758), la Asunción de la Virgen ( $D N, 15$. enero. 1759), san Cayetano de cerca de una vara de alto con dos niños a su lado ( $D N, 2$. marzo. 1759), san Francisco de Paula ( $D N$, 17. enero. 1760), la aparición de la Virgen de la Candelaria ( $D N$, 6. febrero. 1760), Divino Señor ( $D N$, 9. julio. 1760), san Antonio ( $D N$, 6. septiembre. 1760), san Miguel ( $D N, 3$. diciembre. 1761), etc. Más raras fueron las que se ofertaron en otros materiales, podemos citar: un Cristo de bronce con adornos de tres cuartas de alto; una hechura de san Sebastián "de piedra, trabajada con mucho primor, y guarnecida con árbol y algunos Ángeles que traen trofeos, o atributos" ( $D N, 11$ y 25. septiembre. 1758, respectivamente); Santiago a caballo de alabastro con peana de lo mismo de media vara de alto ( $D N$, 4. noviembre. 1761). Es muy posible que también estuvieran destinados a ser expuestos en una urna los "dos carros triunfales de coral, tirados de dos caballos cada uno y una águila de bronce con un ramo de coral grande por detrás en el uno se representa a san Juan en el Desierto y en el otro una imagen de nuestra señora de la Concepción, asimismo se venden dos ramos también de coral con la imagen de santa Rosalía" (DN, 20. mayo. 1760).

Muchas de las esculturas se adquirían en las tiendas de los ebanistas y, como la pintura, en los talleres de los doradores (entre otros se nombra a Francisco Alapuente que vivía en la calle de la Manzana), pero conservamos un anuncio que debió ponerlo el propio escultor que vivía en la calle de Fuencarral, junto al Hospicio, que vendía "dos imágenes de bulto, la una de San Antonio de Padua y la otra de San Francisco de Asís cada una colocada en una urna de cristales correspondientes" tasadas en 2.500 rs. aunque estaba dispuesto a hacer algún tipo de ajuste ( $D N, 10$. agosto. 1758). $\mathrm{Y}$, como rareza, cabe citar la oferta que hizo el ebanista de la calle Valverde de "una imagen de la contemplación de escultura obra de Capuzi muy buena para un oratorio, tiene urna” ( $D N, 23$. agosto. 1758). Por último, también se anunciaron multitud de efigies anónimas sin más, ponderándose su talla, como la Concepción "de escultura muy buena" ( $D N, 27$. abril. 1758) o la Virgen con el Niño que se anunció el 12 de mayo de 1758 tasada en 40 doblones. En este apartado las hechuras de la Inmaculada son las más 
presentes aunque también figuran otras advocaciones de gran devoción local como la Virgen de la Soledad, san Isidro o santa María de la Cabeza.

En cuanto a la escultura de tema profano, ya comentamos que no abunda entre los anuncios del periódico. Sobre los autores, sólo podemos citar a Piamontini, cuya obra, una estatua de mármol de Hércules, se vendía a partir del 1 de diciembre de 1758 junto a una

máquina de bronce, que forma un Pedestal con un caballo y una estatua encima que representa al Rey nuestro Señor (que Dios Prospere), la Máquina es obra de Soldani Toscano, y la figura de Juan Boloña, tiene en cada lado del cuadrángulo los 4 tiempos, diferentes trofeos y las armas de España; 12 pedestales más chicos que representan varias historias de diferentes autores italianos.

Al igual que existía todo un repertorio de figuras de tamaño reducido de asunto religioso, ocurría lo propio con las de tema mitológico, vaciadas en escayola que debían repartirse sobre chimeneas y repisas. El 22 de diciembre de 1762 se anunciaba la venta "de varios moldes nuevos de yeso, que componen las figuras siguientes, el Robo de las Sabinas, el Robo de Deyanira por el Centauro Chirón, una Venus con Cupido, otro de varias medallas de bajo relieve de santo, uno de una cabeza de mujer del tamaño del natural. La distribución de este tipo de pequeñas esculturas seriadas debió de generalizarse a través de la venta ambulante y hay que suponer que, bien por su baja calidad, bien por su temática —el tema mitológico se prestaba al erotismo y "desnudeces" - o por ambas razones fueron objeto de censura por parte del legislador. Así, la Real Cédula de 2 de agosto de 1781, que prohibía la actividad de aquellos que "sin domicilio fijo venden por las calles efigies de yesos, botes de olor, palilleros, anteojos y otras menudencias de esta clase, como Caldereros y Buhoneros que andan por los pueblos y se hallan en todas las ferias, ${ }^{53}$. De mayor tamaño debía ser un grupo de escultura, compuesto de cuatro figuras las cuales representan a Venus, a Adonis, a un Niño y un Perro, todo hecho con mucho primor y delicadamente" que se puso a la venta el 27 de enero de 1759, y seguía en el mercado el 9 de junio, pero no orienta sobre su posible destino. En el caso contrario se encuentran las "dos estatuas de piedra de mármol de Génova, que la una representa a la diosa Venus, su altura es de 4 pies y medio con un Cupido al pie de 2 pies de altura, y la otra, también de Venus, echada, cuyo largo es de tres cuartas y media", porque al ser huecas podían "echar agua por todas partes

${ }^{33}$ La Real Cédula se publicó en Madrid, Imprenta de Pedro Marín, 1781. A comienzos de los años ochenta Juan Panuci o Panuchi, modelista de la Academia de San Fernando, suministraba moldes de escayola a particulares como el infante don Gabriel. 
y especialmente Cupido por el carcaj” ( $D N, 17$. febrero. 1759), dadas estas características es evidente que su destino era el gabinete o el jardín.

El deterioro que sufría la escultura al aire libre es otro tema que encontramos reflejado en el periódico: el 19 de febrero de 1759 ofrecía sus servicios un sujeto para aplicar a este tipo de obras un tratamiento que era muy similar al revoco de las fachadas, o por lo menos esto es lo que se desprende del comunicado, donde declaraba tener la "habilidad para revocar cualquier género de adornos, arquitectura de resaltado, asimismo de cantería como se halla en la casa de la Excelentísima Señora Condesa de Atri, figuras para adornar jardines, con más brevedad que la que gastan los italianos y menos coste, se avisa al público, para que si algún maestro de obra lo quisiere poner en planta u otro cualesquiera sujeto, lo demostrará en un modelo que está en dicha Barbería, según se haya de ejecutar en las fachadas y será más permanente que lo pintado".

Como ocurría con las pinturas, también se hurtaron esculturas en estos años y el Diario Noticioso fue el vehículo para denunciar estos robos antiguos y contemporáneos ${ }^{54}$. Entre los primeros podemos mencionar el que ocurrió en el Mesón del lugar de la Alameda donde "se pusieron por los años de 1728 ó 29 seis estatuas, con sus repisas de alabastro, que tenían de alto a tres cuartas y media" y que fueron vendidas o empeñadas por "un vecino de dicho lugar" sin ser su dueño, y todavía el 17 de abril de 1758 se tenía la esperanza de recuperarlas. Entre los últimos, lo ocurrido los días 9 y 10 de abril de 1758 en que se echó en falta una "figura de Academia en bronce, recostada sobre la mano izquierda y la derecha sobre el pecho, su peso de cuatro libras poco más o menos" ( $D N$, 29. abril. 1758). Este hecho nos da pie para hablar de otra vertiente dentro del comercio de escultura, aquella que era propia para el aprendizaje ya fuera de medicina y cirugía ${ }^{55}$, o de las bellas artes. Unos días después

${ }^{54}$ "La persona que tuviere noticia del paradero de una imagen de escultura de S. Rafael de una vara de alto que se echó de menos el día 27 del corriente en la Iglesia del Convento de nuestra Señora la Real de Atocha acuda a dar aviso al padre sacristán de dicho convento ( $D N, 29$. octubre. 1765).

55 "Se vende una estatua de hombre crecido para el estudio de la cirugía y medicina, para su ajuste se acudirá a la barbería de la calle de Fuencarral" (DN, 4. marzo. $1760)$; también se anunciaba un esqueleto de hombre ( $D N, 7$. octubre. 1760), y, por las páginas del diario, la Real Academia de San Fernando comunicó, el 31 de octubre de 1760 , que se había “jubilado a Pedro Díaz que ha servido por espacio de 15 años el encargo de Modelo de ella concediéndole 4 reales diarios por toda su vida y quedando vacante esta plaza cuya dotación es 250 ducados en cada año se hace notorio al público para que las personas que quieran pretenderla acudan a la Real casa de Panadería a don Juan Moreno y Sánchez conserje de dicha Academia". 
de ese hurto, el 17 de abril, se daba un comunicado con la siguiente información: "En la calle de la Comadre, pasada una casa pintada y una cochera, segunda puerta en el cuarto principal viven unos italianos que tienen para vender diferentes figuras de academia de yeso, cabezas al natural y un estudio de 20 pies grandes y chicosn. Con ese mismo fin docente se anunciaron dos aefigies de barro cocido, de san Jerónimo y la Magdalena penitente, muy especiales y que pueden ser modelos para el Estudio de una Academian ( $D N, 1$. febrero. 1764) $)^{56}$. Y no me resisto a reproducir el aviso al público que se dio en 1784 en la ciudad de Valladolid y que en su día publicara Urrea (1979: 495) en sus apuntes para la historia de la escultura en cera en España:

Han llegado a esta Ciudad D. Hermenegildo Silici, y D. Juan Bautista Salerni, Escultores Italianos, con una Colección de Figuras de cera de regular estatura, hechas por su mano, que han tenido el honor de presentarlas a sus AA. RR. por diez días en su Real Palacio. Estas figuras representan la Historia de Dalila y Sansón el Israelita, que está dormido sobre el muslo izquierdo de Dalila; es Figura anatómica, y manifiesta cuanto se contiene en la cabeza, pecho y vientre humano; asimismo descubre los tegumentos del brazo izquierdo, y se ven los músculos, venas, arterias, y lo demás correspondiente, de que hacen anatómica demostración, dichos Autores, habiendo merecido el mayor aprecio de todos los Profesores de Escultura, y Cirugía que la han visto. Dalila pomposamente vestida en traje Oriental, está sentada en ademán de cortar el cabello al dormido Sansón con las tijeras en una mano, y parte del cabello cortado en la otra; una vieja muy curiosa, confidenta de Dalila, con un dedo puesto en los labios, señalando a los Filisteos que no hagan ruido, para que no despierte el dormido Israelita: uno de los principales Filisteos, en traje majestuoso, está mirando airado y gustoso a un mismo tiempo al dormido Sansón caído víctima de su rabia, con un bolsillo en la mano ofreciendo a Dalila el premio prometido; otro de los más atrevidos con un cordel en las manos para atarle, otro para sujetarle, y otro asomado a la puerta del Gabinete, esperando la ejecución para avisar a los demás, que se supone están ocultos. Finalmente se ve un niño muy gracioso sentado en el suelo, que está jugando con una quijada de un borrico, que ha tomado de la mano de Sansón: en otra sala se ven otras figuras muy curiosas.

\section{BiBLIOGRAFÍA CITADA}

AA.VV. 1926. Catálogo de la Exposición del Antiguo Madrid. Madrid: Gráficas Reunidas. ÁlVAREZ DE QuiNDÓs, JUAN ANTONIO. 1982. Descripción bistórica del Real Bosque y Casa de Aranjuez. Madrid: Ayuntamiento de Aranjuez, ed. facsímil.

${ }^{56}$ Hay que recordar que entre las figuras de los nacimientos se encontraban las "academias", modeladas enteramente de barro y que también eran excelentes modelos de enseñanza, un ejemplo es el mendigo del belén napolitano del Museo Nacional de Escultura de Valladolid (Fernández González 1999: 20). 
BlanCo MOzO, JUAN LuIS. 1998. "Varia paretiana: I. La familia Fourdinier. II. Paret en el País Vasco: su relación con algunos miembros de la Real Sociedad Bascongada de los Amigos del País", en I Congreso Internacional "Pintura Española siglo XVII": 299-316. Málaga: Fundación Museo del Grabado Español Contemporáneo.

BOyD, AleXANDER. ed. 1954. The Journal of William Beckford in Portugal and Spain 1787-1788, Londres: Rupert Hart Davis.

CAUSA, RAFFAello. "El belén cortesano", en N. Spinosa, El arte en la Corte de Nápoles en el siglo XVIII: 295-298. Madrid: Ministerio de Cultura.

CEA GUTIÉRREZ, ANTONIO. 1992 Religiosidad popular. Imágenes vestideras. Zamora: Caja España.

- 1993. "Coleccionismo y devociones domésticas en la Sierra de Francia y Candelario (Salamanca, siglos XVII-XIX)». Revista de Dialectología y Tradiciones Populares XLVIII 2: $213-288$

- 2000. "Fiesta, función, regocijos: claves religiosas y lúdicas en la sociedad rural salmantina del siglo XviII. La obra de quita y pon", en M. Torrione (ed.), España festejante. El siglo XVIII: 127-143. Málaga: Diputación de Málaga.

CEÁn Bermúdez, JuAn Agustín. 1800. Diccionario bistórico de los más ilustres profesores de las Bellas Artes en España, Madrid, Real Academia de Bellas Artes de San Fernando.

CIECHANOWIECKI, ANDREW. S. 1990. "La escultura en Nápoles", en N. Spinosa, El arte en la Corte de Nápoles en el siglo XVII: 43-54. Madrid: Ministerio de Cultura.

Estella, Margarita. 1976. "Tres obras de Nicolás Fumo, de paradero actual desconocido". Archivo Español de Arte 193: 80-85.

-. 1993. "Obras maestras inéditas del arte de la cera en España". Goya 237: 149-160.

FERNÁNDEZ GONZÁlez, Rosario. 1999. “El Belén Napolitano del Museo Nacional de Escultura", en Navidad en Palacio. Belenes Napolitanos: 18-25. Madrid: Patrimonio Nacional.

FERNÁNDEZ De NAVARRETE, PEDRO. 1626. Conservación de monarquías. Discursos politicos sobre la gran consulta que el Consejo bizo al Señor Rey don Felipe Tercero. Madrid: Imprenta Real.

GLENDINNING, Nigel. 1983. Goya y sus críticos. Madrid: Taurus.

HeRRERO CARRETERO, CONCHA. 1996. "La Real Fábrica de tapices de Madrid y las innovaciones en tiempos de Francisco de Goyan, en Realidad y sueño en los viajes de Goya: 69-85. Fuendetodos (Zaragoza): Diputación de Zaragoza.

- 2004. "La Fortaleza, cortina de la Colgadura del Dormitorio de Carlos III en el palacio nuevo de Madrid. Reales Sitios 161: 24-35.

Herrero Sanz, María Jesús. 1998. "El Belén del Príncipe en el Palacio Real de Madrid: origen, desarrollo y actualidad", en Navidad en palacio: Reales Sitios, Monasterios y Salzillo: 27-35. Madrid: Patrimonio Nacional.

KlAPISCH-ZuBER, CHRISTIANE. 1985. Women, Family, and Ritual in Renaissance Italy. Chicago: The University of Chicago Press.

MARÍAS, FERNANDO. 1995. "De retablero a retablista", en AA. VV., Retablos de la Comunidad de Madrid: 97-109. Madrid: Comunidad de Madrid.

Martínez Burgos, Palma. 1990. Ídolos e Imágenes. La controversia del arte religioso en el siglo XVI español. Valladolid: Universidad de Valladolid.

MARTíNEZ JUSTICIA, MARÍA JOSÉ. 2000. Historia y teoría de la conservación y restauración artística. Madrid: Tecnos.

Palomino, ANTONIO. 1947 [1715-1724]. El museo pictórico y escala óptica. Madrid: Aguilar. 
PÉREZ SÁNCHEZ, Alfonso Emilıo. 1995. "Retablos madrileños del siglo XVII", en AA. VV., Retablos de la Comunidad de Madrid: 59-76. Madrid: Comunidad de Madrid.

PONZ, ANTONIO. 1947 [1772-1794]. Viaje de España. Madrid: Aguilar.

PORTÚs, JAVIER. y VeGA, JeSUSA. 1998. La estampa religiosa en la España del Antiguo Régimen. Madrid: FUE.

PRAZ, MARIO. 2004. La casa de la vida. Barcelona: Debolsillo.

Ringrose, David. R. 1985. Madrid y la economía española, 1560-1850. Ciudad, Corte y País en el Antiguo Régimen. Madrid: Alianza.

SÁNCHEZ VIDAL, Agustín. 1994. Los Gimeno y los origenes del cine en Zaragoza. Zaragoza: Ayuntamiento de Zaragoza.

TOMÉ DE LA VeGA, F. 1998. "El Gabinete de los pájaros del Infante Don Luis". Reales Sitios 137: 10-21.

TORRES Villarroel, Diego de 1991 [1727-1728]. Visiones y visitas con don Francisco de Quevedo por la Corte. Madrid: Espasa Calpe, ed. Russell P. Sebold.

TOVAR MarTín, Virginia. 1995. "El retablo madrileño en el siglo XVIII", en AA. VV., Retablos de la Comunidad de Madrid: 77-96. Madrid: Comunidad de Madrid.

- 1996. "El gabinete de la Reina en el Palacio de Aranjuez (siglo XVIII)". Reales Sitios 127: $35-44$.

URREA, JESÚs. 1979. "Apuntes para el estudio de la escultura de cera en España". Boletín del Seminario de Arte y Arqueología XLV: 488-495.

VALVERDE PÉREZ, NURIA. 2003. "Instrumentos científicos, opinión pública y economía moral en la Ilustración Españolan. Tesis doctoral, Universidad Autónoma de Madrid.

VAREY, JOSEPH E. 1995. Cartelera de títeres y otras diversiones populares de Madrid: 17581840, Londres; Támesis.

VEGA, JESUSA. 2000. "Contextos cotidianos para el arte. Cuadros y objetos de arte para el adorno doméstico madrileño a mediados del siglo XVIII. Revista de Dialectología $y$ Tradiciones Populares LV 1: 5-43. 